\title{
Enantioselective Addition of Aryl Ketones and Acetone to Nitroalkenes Organocatalyzed by Carbamate-Monoprotected Cyclohexa-1,2-Diamines
}

\author{
Jesús Flores-Ferrándiz ${ }^{\mathrm{a}}$, Alexander Stiven, ${ }^{\mathrm{a}}$ Lia Sotorríos, ${ }^{\mathrm{b}}$ Enrique Gómez-Bengoa, \\ Rafael Chinchilla, ${ }^{\mathrm{a}}$ * \\ ${ }^{a}$ Departamento de Química Orgánica, Facultad de Ciencias, and Instituto de Síntesis Orgánica (ISO), \\ Universidad de Alicante, Apdo. 99, 03080 Alicante, Spain \\ ${ }^{b}$ Departamento de Química Orgánica I, Universidad del País Vasco, Apdo. 1072, 20080 San Sebastíán, Spain
}

\begin{abstract}
Enantiomerically pure carbamate-monoprotected trans-cyclohexane-1,2-diamines are used as chiral organocatalysts for the addition of aryl ketones and acetone to nitroalkenes leading to enantioenriched $\beta$-substituted $\gamma$-nitroketones. The reaction is performed in the presence of 3,4-dimethoxybenzoic acid as additive, in chloroform as solvent at room temperature, achieving enantioselectivities up to $96 \%$. Theoretical calculations are used to justify the observed sense of the stereoinduction.
\end{abstract}

\section{Introduction}

The enantioselective preparation of $\gamma$-nitrocarbonyl compounds is an interesting synthetic topic nowadays, as they are precursors of important compounds such as alkaloids, ${ }^{1}$ aminoacids, ${ }^{2}$ antitumorals, ${ }^{3}$ antibiotics, ${ }^{4}$ peptidomimetics, $^{5}$ and marine metabolites ${ }^{6}$, among others. $^{7}$ The direct conjugate addition of carbonyl compounds to conjugated nitroalkenes by means of metalfree organic catalysts represents a convenient access to this type of compounds. Therefore, over the past years, much progress has been made in the development of organocatalytic-based methodologies for accomplishing this task. ${ }^{8}$

Nonetheless, the direct organocatalytic asymmetric conjugate addition of aromatic ketones to nitroalkenes still is considered a "difficult" process much less explored. Thus, the enantioselective addition of aromatic ketones to $\beta$-nitrostyrenes is particularly interesting, as the corresponding $\gamma$-nitroketones can be used as intermediates in the preparation of $\beta$-arylated $\gamma$-aminobutyric acids, which are pharmacologically important $\mathrm{GABA}_{\mathrm{B}}$ agonists. ${ }^{9}$ Commercial examples are baclofen, ${ }^{10}$ used in the treatment of spasticity, or phenibut, ${ }^{11}$ a tranquilizer and nootropic drug.

Although the enantioselective addition of particular aryl ketones, such as acetophenone, to $\beta$-nitrostyrene has been described using proline ${ }^{12}$ or proline-derived organocatalysts, ${ }^{13}$ most of the reported procedures using arylated ketones and nitroalkenes involve the use of chiral primary amine-containing $\mathrm{NH}$-functionalized species, such as amides, ${ }^{14}$ sulfonamides ${ }^{15}$ and thioureas, ${ }^{16}$ the last ones achieving the best results. Using these primary amine-containing bifunctional organocatalysts, the enantioselectivity is induced by addition of a transient enamine to the nitroolefin, which is hydrogen bondcoordinated by the $\mathrm{NH}$ group of the additional functionality.

We have recently reported the use of primary amines from chiral trans-cyclohexane-1,2-diamines 1-3, monosubstituted with the common Boc, Cbz, and Fmoc protecting groups, respectively, as organocatalysts in the enantioselective Michael addition reaction of aldehydes to maleimides. ${ }^{17}$ Is this paper we present the use of these simple primary amine-containing species as chiral organocatalysts in the conjugate addition reaction of arylated ketones, or even acetone, to nitroalkenes, leading to enantioenriched $\beta$-substituted $\gamma$-nitroketones. Theoretical calculations have been used to explain the observed sense of enantioselectivity.<smiles>CCOC(=O)N[C@H]1CCCC[C@H]1N</smiles><smiles>N[C@@H]1CCCC[C@H]1NC(=O)OCc1ccccc1</smiles><smiles>NC1CCCCC1NC(=O)OCC1c2ccccc2-c2ccccc21</smiles>

\footnotetext{
*Corresponding author. Tel.: +34-96-5903728; fax: +34-96-5903549; e-mail: enrique.gomez@ehu.es (E. Gómez-Bengoa), chinchilla@ua.es (R. Chinchilla).
} 


\section{Results and discussion}

The carbamate-monoprotected primary amines 1-3 employed as organocatalysts in this study were prepared by monoprotection of $(1 S, 2 S)$-cyclohexane-1,2-diamine with the common tert-butoxycarbonyl (Boc), benzyloxycarbonyl (Cbz) and fluorenylmethoxycarbonyl (Fmoc) groups as previously reported. ${ }^{17 \mathrm{~b}}$ The search for the most appropriate organocatalyst and reaction conditions (Table 1) began using the model conjugate addition reaction of acetophenone (4a) (2 equiv) to $(E)-\beta$ nitrostyrene (5a), organocatalyzed by $1(20 \mathrm{~mol} \%)$ in toluene as solvent at room temperature, which afforded the corresponding adduct $(R)-\mathbf{6 a a}$ in $62 \%$ isolated yield and with a $88 \%$ ee after 5 d reaction time (Table 1, entry $1)$. The $(R)$ absolute configuration of the final adduct was determined by comparison of the elution order of the corresponding enantiomers in chiral HPLC with those in the literature. ${ }^{16 \mathrm{c}}$ This adduct $(R)-\mathbf{6 a a}$ is a precursor of the drug baclofen. ${ }^{16 \mathrm{~h}}$

When the Cbz-monoprotected diamine $\mathbf{2}$ was used as organocatalyst under these reaction conditions, the enantioselectivy of the process remained unchanged, although the isolated yield of the final adduct diminished (Table 1, entry 2). In addition, when the Fmocmonoprotected primary amine $\mathbf{3}$ was employed, the enantioselectivity was lowered down to $68 \%$ (Table 1, entry 3). Therefore, we choose the Boc-containing primary amine $\mathbf{1}$ as organocatalyst for the rest of the study.
The use of others solvents was also explored. Thus, dichloromethane and chloroform were attempted, the last one raising slightly both yield and enantioselectivity (Table 1, entries 4 and 5), whereas the use of hexane or ether diminished both values (Table 1, entries 6 and 7). In addition, a polar solvent such as DMF afforded only a $50 \%$ ee of $(R)-6 \mathbf{a a}$, and a protic one such as water proved not beneficial (Table 1, entries 8 and 9). Moreover, the use of a combination of DMF/water $(2 / 1, \mathrm{v} / \mathrm{v})$, a solvent mixture that has proven effective in the enantioselective conjugate addition of aldehydes to maleimides organocatalyzed by $\mathbf{1},{ }^{17}$ gave a poor enantioselection (Table 1, entry 10).

We then explore the effect of the addition of some additives to the reaction, employing chloroform as the reaction solvent. Thus, the addition of the basic imidazole (20 mol\%), something that proved beneficial in some conjugate addition reactions, ${ }^{8}$ was detrimental for the enantioselectivity in this case, compared to when no additive was used (Table 1, compare entries 5 and 11). Therefore, we switched to the use of carboxylic acids as additives $(20 \mathrm{~mol} \%)$, as it is known that they can facilitate the interconversion of the different intermediates of the catalytic enamine cycle. ${ }^{8 \mathrm{~g} ; 19}$ Thus, the addition of benzoic acid $(20 \mathrm{~mol} \%)$ resulted in a slight improvement of yield and enantioselectivity compared to when no additive was used (Table 1, compare entries 5 and 12). This positive result prompted us to explore if a modulation of the $\mathrm{pKa}$ of the additive by changing the substituent in the aromatic ring could be beneficial.

Table 1. Screening and optimization of the reaction conditions for the enantioselective addition reaction of acetophenone to $(E)-\beta$-nitrostyrene.

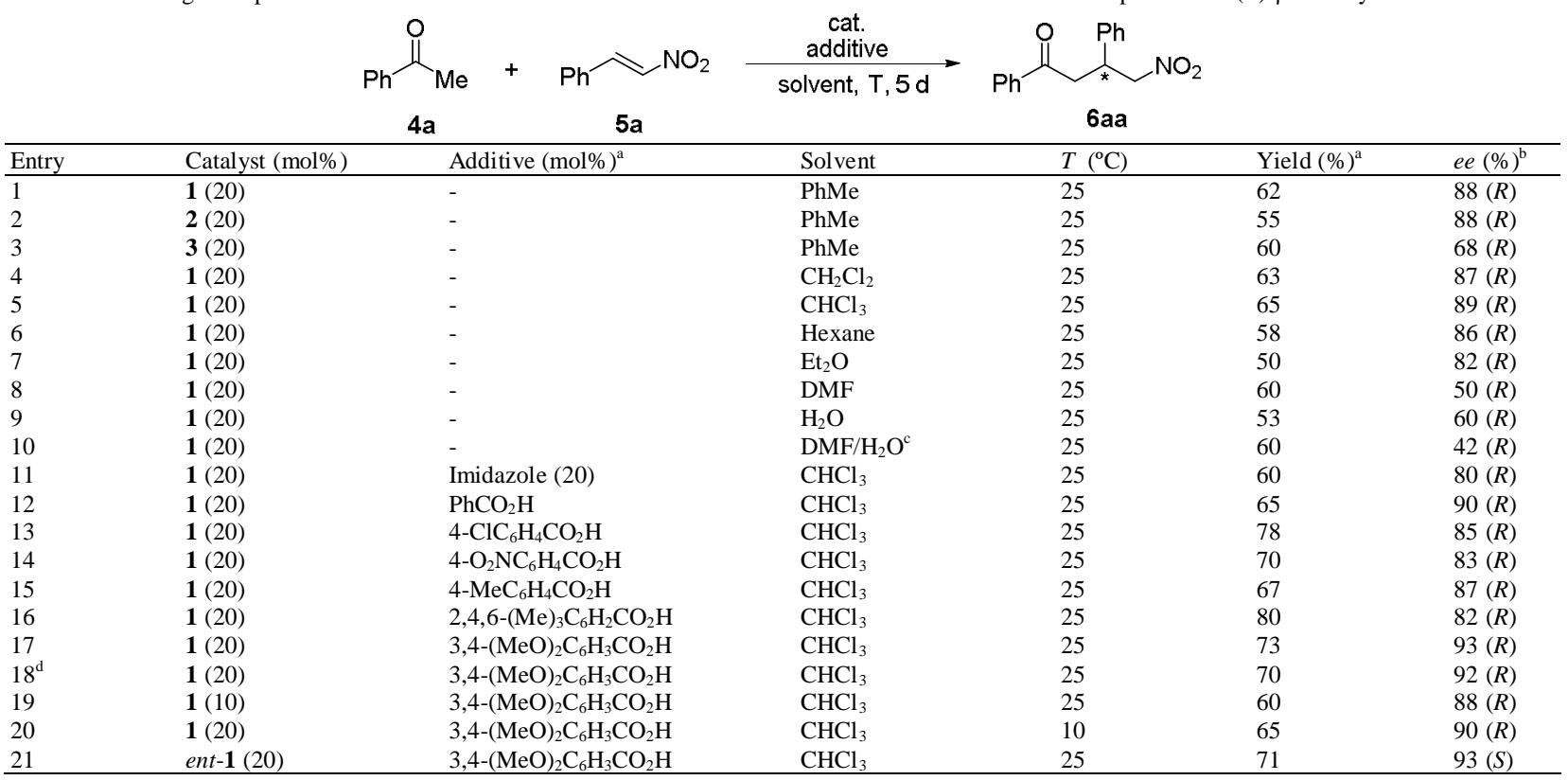

Isolated yield after flash chromatography.

${ }^{\mathrm{b}}$ Enantioselectivities and absolute stereochemistry determined by chiral HPLC (Ref. 16c)

c $2 / 1, \mathrm{v} / \mathrm{v}$.

d 5 equiv of $\mathbf{4 a}$ were used. 
The presence of electron-withdrawing groups in the aromatic ring of the acid additive, such as chloro or nitro, increased the yield of adduct $(R)$-6aa, although reduced the enantioselectivity of the process (Table 1, entries 13 and 14). Therefore, the presence of additives bearing electron-releasing groups, such as methyl or methoxy was explored (Table 1, entries 15-17). Among them, the best results were achieved when 3,4-dimethoxybenzoic acid was used as additive (Table 1, entry 17), giving rise to $\gamma$-nitroketone $(R)$-6aa in a $93 \%$ ee (Table 1, entry 17 ). Although not spectacular, the presence of this acid additive was slightly positive for the enantioselectivity, but mainly for the chemical yield.

Keeping the most effective reaction conditions [1 (20 mol\%), 3,4-dimethoxybenzoic acid (20 mol\%), $\mathrm{CHCl}_{3}, 25$ $\left.{ }^{\circ} \mathrm{C}\right]$, other parameter changes were explored. Thus, the stoichiometry of the reaction was modified and 5 equiv of acetophenone was used, no significant changes being observed in yield nor stereoselectivity (Table 1, entry 18). In addition, the organocatalyst loading was reduced to 10 mol\%, but the former values diminished (Table 1, entry 19). This also happened when the reaction temperature was lowered down to $10^{\circ} \mathrm{C}$ (Table 1 , entry 20).

Expecting to achieve an opposite enantioselection, we also performed the reaction using as organocatalyst ent-1, which was prepared similarly but using $(1 R, 2 R)$ cyclohexane-1,2-diamine as chirality source. ${ }^{17 b}$ Using this primary amine as organocatalyst $(20 \mathrm{~mol} \%)$ under the most effective reaction conditions [3,4-dimethoxybenzoic acid $\left.(20 \mathrm{~mol} \%), \mathrm{CHCl}_{3}, 25^{\circ} \mathrm{C}\right]$, the expected adduct $(S)$ 6a was isolated in $93 \%$ ee (Table 1, entry 21 ).

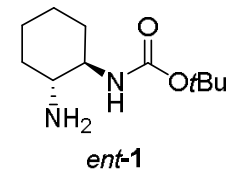

Next we explore the scope of this organocatalyzed conjugate addition reaction by modifying the ketone and the nitroalkene under the most favourable reaction conditions [1 (20 mol\%), 3,4-dimethoxybenzoic acid (20 $\left.\mathrm{mol} \%), \mathrm{CHCl}_{3}, 25{ }^{\circ} \mathrm{C}\right]$, the obtained results being summarized in Table 2.

First, we performed the reaction of arylated ketones $\mathbf{4}$, differently substituted on the aromatic ring, to $(E)-\beta$ nitrostyrene (5a). Thus, when an electron-releasing group such as a methyl was present at the 3- and 4-position of the aromatic ring (4b and $\mathbf{4 c}$ ), the resulting adducts $(R)$ 6ba and $(R)-6$ ca were obtained in 86 and $91 \%$ ee, respectively (Table 2 , entries 2 and 3 ), whereas the presence of a 4-methoxy substituent (4d) yielded $(R)-\mathbf{6 d a}$ also in $91 \%$ ee (Table 2, entry 4 ). The presence of halogens in the aromatic ring, as in the case of ketones $\mathbf{4 e}$ i, gave rise to the corresponding adducts $(R)$-6ea-ia, their enantioselectivities being in the range $85-88 \%$ (Table 2 , entries 5-9). In addition, the presence of other electronwithdrawing substituents, such as the trifluoromethyl $(\mathbf{4} \mathbf{j}$, 4k) and nitro (4l) groups, resulted in lower enantioselections for the corresponding adducts $(R)-\mathbf{6 j a}$, $(R)$-6ka and $(R)$-6la (Table 2, entries 10-12). Moreover, the use of a polyaromatic ketone such as 1-(naphthalen-2yl)ethan-1-one (4m) afforded the $\gamma$-nitroketone $(R)$-6ma in $89 \%$ ee (Table 2, entry 13), whereas the use of a heteroaromatic ketone such as 1-(pyridin-2-yl)ethan-1one $(4 n)$ yielded the corresponding adduct $(R)$-6na in a much lower $68 \%$ ee (Table 2, entry 14 ).

We then explore the influence of changing the substituent on the nitroalkene 5. Thus, when a 4-methyl was present on the aromatic ring $(\mathbf{5 b})$, the resulting $(R)$ 6ab was isolated in $90 \% e e$, a similar value to when a 4methoxy group $(\mathbf{5 c})$ was present $[(R)-6 \mathbf{a c}, 89 \%$ ee $]$ (Table 2 , entries 15 and 16). In addition, when other electronreleasing systems were present, as in the case of the dioxole moiety (5d) and 3,4,5-trimethoxy groups $(\mathbf{5 e})$, the enantioselectivities for the obtained adducts $(R)-6 \mathbf{a d}$ and $(R)$-6ae were 90 and $89 \%$, respectively (Table 2, entries 17 and 18).

When halogen groups were present on the aromatic ring of $\mathbf{5}(\mathbf{5} \mathbf{f}-\mathbf{i})$, the corresponding $\boldsymbol{\gamma}$-nitroketones $(R)-\mathbf{6 a f}$ ai) were isolated with enantioselectivities ranging from 86 to $93 \%$ (Table 2, entries 19-22). Adduct $(R)$-6ah results particularly interesting, as is an intermediate in the preparation of the commercial drug phenibut. ${ }^{16 \mathrm{~h}}$ In addition, the presence of other electron-withdrawing substituents such as the 4-trifluoromethyl (5j) and 4-nitro $(\mathbf{5 k})$ afforded adducts $(R)-\mathbf{6 a j}$ and $(R)$-6ak in 87 and $88 \%$ $e e$, respectively (Table 2, entries 23 and 24). Moreover, the presence of a system such as the 2-naphthyl (5l) allowed to prepare $(R)-6$ al in $90 \%$ ee (Table 2, entry 25), and the use of heteroaromatic systems such as a 3-pyridyl $(\mathbf{5 m})$ and 2-furanyl (5n) yielded $\gamma$-nitroketones $(R)$-6am and $(S)$-6an (no change in the enantioselectivity sense, just an effect of the CIP rules), with enantioselections of 86 and 96\%, respectively (Table 2, entries 26 and 27).

Finally, we explored the use of organocatalyst $\mathbf{1}$, under the former reaction conditions, in the conjugate addition of the simple acetone ( 5 equiv), to these nitroalkenes (Table 2). Thus, when acetone (4o) reacted with $(E)-\beta$ nitrostyrene (5a), the corresponding $\gamma$-nitroketone $(R)$-60a was isolated in a $92 \%$ yield and in $70 \%$ ee (Table 2, entry $28)$. When a 4-methyl or a 4-methoxy group was present in the nitroalkene, the corresponding adducts $(R)-60 b$ and $(R)$-6oc were obtained in 67 and $70 \%$ ee, respectively (Table 2, entries 29 and 30), whereas the presence of halogen groups such as a 4-fluoro and 4-chloro gave rise to higher enantioselections of the isolated adducts $(R)$-6of and $(R)-\mathbf{6 o h}$, respectively (Table 2, entries 31 and 32). However, the reaction with a 4-trifluoromethylated nitroalkene $(\mathbf{5 j})$ produced a lower enantioselectivity for the $\gamma$-nitroketone $(R)-\mathbf{6 o j}$ (Table 2, entry 33), as well as when using the 2-naphthyl-nitroalkene 5j (Table 2, entry $34)$. Finally, a higher enantioselection for adduct $(S)$-6on (84\%) was observed when using a 2-furanyl as substituent in the nitroalkene (5n) (Table 2, entry 35). 
Tetrahedron: Asymmetry

Table 2. Enantioselective addition of ketones to nitroalkenes organocatalyzed by 1 .

\begin{tabular}{|c|c|c|c|c|c|c|c|c|}
\hline \multirow{3}{*}{ Entry } & \multicolumn{2}{|c|}{4} & $+\mathrm{R}^{2} \underset{5}{-}$ & \multicolumn{2}{|c|}{$\begin{array}{c}1\left(20 \mathrm{~mol}^{\circ}\right) \\
3,4-(\mathrm{MeO})_{2} \mathrm{C}_{6} \mathrm{H}_{3} \mathrm{CO}_{2} \mathrm{H} \\
\left(20 \mathrm{~mol}^{2}\right)\end{array}$} & O $\quad \mathrm{R}^{2}$ & \multirow{3}{*}{ Yield $(\%)^{\mathrm{b}}$} & \multirow{3}{*}{$e e(\%)^{\mathrm{c}, \mathrm{c}}$} \\
\hline & \multicolumn{2}{|c|}{ Ketone $^{a}$} & \multicolumn{2}{|c|}{ Nitroalkene } & \multirow[t]{2}{*}{$t(\mathrm{~d})$} & \multirow{2}{*}{ Adduct No. } & & \\
\hline & $\mathrm{R}^{1}$ & No. & $\mathrm{R}^{2}$ & No. & & & & \\
\hline 1 & $\mathrm{Ph}$ & $4 a$ & $\mathrm{Ph}$ & $5 \mathbf{5 a}$ & 5 & $(R)-\mathbf{6 a a}$ & 73 & 93 \\
\hline 2 & $3-\mathrm{MeC}_{6} \mathrm{H}_{4}$ & $4 b$ & $\mathrm{Ph}$ & $5 \mathbf{a}$ & 5 & $(R)-\mathbf{6 b a}$ & 70 & 86 \\
\hline 3 & 4- $\mathrm{MeC}_{6} \mathrm{H}_{4}$ & $4 c$ & $\mathrm{Ph}$ & $5 \mathbf{a}$ & 5 & $(R)-6 \mathbf{c a}$ & 70 & 91 \\
\hline 4 & $4-\mathrm{MeOC}_{6} \mathrm{H}_{4}$ & 4d & $\mathrm{Ph}$ & $5 \mathbf{a}$ & 5 & $(R)-\mathbf{6 d a}$ & 63 & 91 \\
\hline 5 & $4-\mathrm{FC}_{6} \mathrm{H}_{4}$ & $4 e$ & $\mathrm{Ph}$ & $5 \mathbf{a}$ & 5 & $(R)-6 \mathrm{ea}$ & 68 & 88 \\
\hline 6 & $3-\mathrm{ClC}_{6} \mathrm{H}_{4}$ & 4f & $\mathrm{Ph}$ & $5 \mathbf{a}$ & 5 & $(R)-\mathbf{6 f a}$ & 68 & 85 \\
\hline 7 & 4- $\mathrm{ClC}_{6} \mathrm{H}_{4}$ & $4 g$ & $\mathrm{Ph}$ & $5 \mathbf{a}$ & 5 & $(R)-6 \mathrm{ga}$ & 70 & 86 \\
\hline 8 & $4-\mathrm{BrC}_{6} \mathrm{H}_{4}$ & $4 \mathrm{~h}$ & $\mathrm{Ph}$ & $5 a$ & 5 & $(R)-6 \mathbf{h a}$ & 70 & 88 \\
\hline 9 & 4- $\mathrm{IC}_{6} \mathrm{H}_{4}$ & $4 i$ & $\mathrm{Ph}$ & $5 \mathbf{a}$ & 5 & $(R)-6 \mathbf{i a}$ & 67 & 88 \\
\hline 10 & $3-\mathrm{F}_{3} \mathrm{CC}_{6} \mathrm{H}_{4}$ & $4 j$ & $\mathrm{Ph}$ & $5 \mathbf{a}$ & 5 & $(R)-\mathbf{6 j a}$ & 71 & 82 \\
\hline 11 & $4-\mathrm{F}_{3} \mathrm{CC}_{6} \mathrm{H}_{4}$ & $4 k$ & $\mathrm{Ph}$ & $5 \mathbf{a}$ & 5 & $(R)-6 \mathbf{k a}$ & 68 & 83 \\
\hline 12 & $4-\mathrm{O}_{2} \mathrm{NC}_{6} \mathrm{H}_{4}$ & 41 & $\mathrm{Ph}$ & $5 \mathbf{a}$ & 5 & $(R)$-6la & 58 & 75 \\
\hline 13 & 2-Naphthyl & $4 m$ & $\mathrm{Ph}$ & $5 \mathbf{a}$ & 5 & $(R)-6 \mathrm{ma}$ & 71 & 89 \\
\hline 14 & 2-Pyridinyl & $4 n$ & $\mathrm{Ph}$ & $5 \mathbf{a}$ & 5 & $(R)-6$ na & 85 & 68 \\
\hline 15 & $\mathrm{Ph}$ & $\mathbf{4 a}$ & 4- $\mathrm{MeC}_{6} \mathrm{H}_{4}$ & $\mathbf{5 b}$ & 5 & $(R)-\mathbf{6 a b}$ & 70 & 90 \\
\hline 16 & $\mathrm{Ph}$ & $\mathbf{4 a}$ & 4- $\mathrm{MeOC}_{6} \mathrm{H}_{4}$ & $5 c$ & 5 & $(R)-6 \mathbf{a c}$ & 72 & 89 \\
\hline 17 & $\mathrm{Ph}$ & $\mathbf{4 a}$ & $3,4-\left(\mathrm{OCH}_{2} \mathrm{O}\right) \mathrm{C}_{6} \mathrm{H}_{3}$ & $5 d$ & 5 & $(R)-6 \mathbf{a d}$ & 60 & 90 \\
\hline 18 & $\mathrm{Ph}$ & $\mathbf{4 a}$ & $3,4,5-(\mathrm{MeO})_{3} \mathrm{C}_{6} \mathrm{H}_{2}$ & $5 e$ & 5 & $(R)-6 \mathbf{a e}$ & 56 & 89 \\
\hline 19 & $\mathrm{Ph}$ & $\mathbf{4 a}$ & $4-\mathrm{FC}_{6} \mathrm{H}_{4}$ & $5 f$ & 5 & (R)-6af & 75 & 87 \\
\hline 20 & $\mathrm{Ph}$ & $4 \mathbf{a}$ & $2-\mathrm{ClC}_{6} \mathrm{H}_{4}$ & $5 g$ & 5 & $(R)-\mathbf{6 a g}$ & 77 & 93 \\
\hline 21 & $\mathrm{Ph}$ & $\mathbf{4 a}$ & 4- $\mathrm{ClC}_{6} \mathrm{H}_{4}$ & $5 h$ & 5 & (R)-6ah & 73 & 90 \\
\hline 22 & $\mathrm{Ph}$ & $\mathbf{4 a}$ & 4- $\mathrm{BrC}_{6} \mathrm{H}_{4}$ & $5 \mathbf{i}$ & 5 & $(R)-\mathbf{6 a i}$ & 70 & 86 \\
\hline 23 & $\mathrm{Ph}$ & $4 \mathbf{a}$ & $4-\mathrm{F}_{3} \mathrm{CC}_{6} \mathrm{H}_{4}$ & $5 \mathbf{j}$ & 5 & $(R)-\mathbf{6 a j}$ & 68 & 87 \\
\hline 24 & $\mathrm{Ph}$ & $4 a$ & $4-\mathrm{O}_{2} \mathrm{NC}_{6} \mathrm{H}_{4}$ & $5 \mathbf{k}$ & 5 & $(R)-6 \mathbf{a k}$ & 75 & 88 \\
\hline 25 & $\mathrm{Ph}$ & $4 a$ & 2-Naphthyl & 51 & 5 & $(R)-6$ al & 69 & 90 \\
\hline 26 & $\mathrm{Ph}$ & $\mathbf{4 a}$ & 3-Pyridinyl & $5 \mathrm{~m}$ & 5 & (R)-6am & 70 & 86 \\
\hline 27 & $\mathrm{Ph}$ & $4 a$ & 2-Furanyl & $5 n$ & 5 & $(S)$-6an & 74 & 96 \\
\hline 28 & $\mathrm{Me}$ & 40 & $\mathrm{Ph}$ & $\mathbf{5 a}$ & 3 & $(R)-60 a$ & 92 & 70 \\
\hline 29 & $\mathrm{Me}$ & 40 & 4- $\mathrm{MeC}_{6} \mathrm{H}_{4}$ & $\mathbf{5 b}$ & 3 & $(R)-6 o b$ & 85 & 67 \\
\hline 30 & $\mathrm{Me}$ & 40 & $4-\mathrm{MeOC}_{6} \mathrm{H}_{4}$ & $5 c$ & 3 & $(R)-60 c$ & 85 & 70 \\
\hline 31 & $\mathrm{Me}$ & 40 & $4-\mathrm{FC}_{6} \mathrm{H}_{4}$ & 5f & 3 & $(R)-60 f$ & 79 & 74 \\
\hline 32 & $\mathrm{Me}$ & 40 & 4- $\mathrm{ClC}_{6} \mathrm{H}_{4}$ & $5 h$ & 3 & $(R)-6 o h$ & 87 & 78 \\
\hline 33 & $\mathrm{Me}$ & 40 & $4-\mathrm{F}_{3} \mathrm{CC}_{6} \mathrm{H}_{4}$ & $5 \mathbf{j}$ & 3 & $(R)-60 \mathbf{j}$ & 70 & 69 \\
\hline 34 & $\mathrm{Me}$ & 40 & 2-Naphthyl & 51 & 3 & $(R)-60 l$ & 71 & 62 \\
\hline 35 & $\mathrm{Me}$ & 40 & 2-Furanyl & $5 n$ & 3 & $(S)$-6on & 78 & 84 \\
\hline
\end{tabular}

a 2 equiv of $\mathbf{4 a}-\mathbf{n}$ were used; 5 equiv of $\mathbf{4 0}$ were used.

${ }^{\mathrm{b}}$ Isolated yield after flash chromatography.

${ }^{\mathrm{c}}$ Enantioselectivities determined by chiral HPLC.

${ }^{\mathrm{d}}$ Absolute configuration assigned by the order of elution of the enantiomers in chiral HPLC (See Experimental).

In order to justify the origin and sense of the observed enantioselectivity, we carried out theoretical calculations on the reactions of acetophenone (4a) and acetone (4o) with nitrostyrene $\mathbf{5 a}$, catalyzed by the NHBoc derivative 1. We made use of different computational methods (M06-2X and B3LYP-D3, see the Calculations section), and conditions, like the gas phase system and a water solvent model, as extreme situations of apolar and very polar environments. In fact, the choice of solvent has been shown experimentally to have a significant impact on the enantioselectivity (Table 1), and we were intrigued by the high $e e^{\prime} \mathrm{s}$ that are obtained in chloroform and other apolar solvents, while the use of water or DMF has been shown to be detrimental for the observed selectivity.

Following the literature evidence, and our own previous calculations, we assumed that the reaction is taking place through the Seebach's synclinal model ${ }^{20}$ where the nitroalkene is approaching the enamine through an endo-type transition state (Figure 1, left). In that model, the attack from the lower face of the enamine (from our point of view) stereo-specifically determines the formation of the $R$ product through reaction with the $R e$ face of nitrostyrene. Consequently, the approach from the upper face of the enamine (not shown) would deliver the $S$ product. The exo variant of the reaction would lead to opposite results, but according to Seebach's model and our initial calculations, this alternative is not operative and can be safely discarded. 

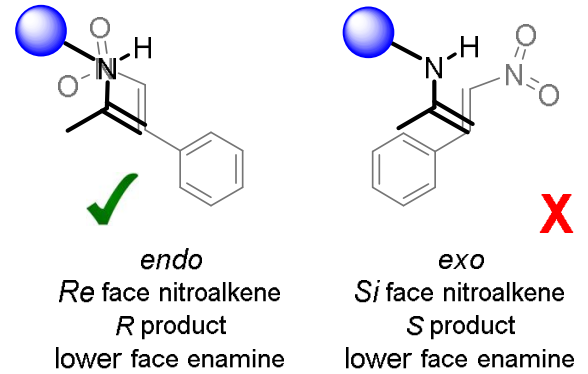

Figure 1. Seebach's synclinal model (left) for the reaction of the enamine model and nitrostyrene.

We have previously studied a related reaction (enamine + maleimide), which was also catalyzed by $\mathbf{1},{ }^{17 \mathrm{~b}}$ finding that the polarity of the solvent has an effect on the conformation of the catalyst, and more significantly, on the differential stabilization of the diastereomeric transition states. Thus, in the simplest alternative, the electrophile can be activated by an intramolecular H-bond with the NHBoc hydrogen of the catalyst $\mathbf{T S A}_{\mathbf{M e}}-\mathbf{R}$ and $\mathbf{T S A}_{\mathbf{P h}}-\mathbf{R}$, Figure 2). Due to the relative disposition of the $\mathrm{NH}$ groups of the enamine and the NHBoc moieties, the electrophile shows a clear preference for the approach through the lower face of the enamine, leading to the formation of the $R$ products. This effect is independent of the source of the enamine, either coming from acetone or acetophenone.

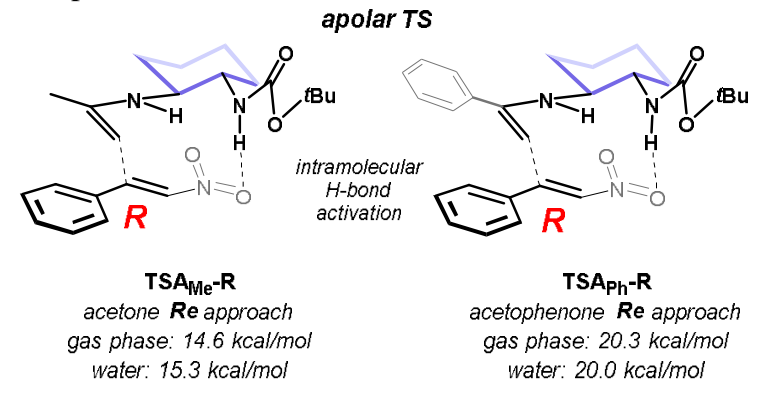

Figure 2. Computed Gibbs Free activation energies for the TSA-type transition states in the gas phase and water models.

The presence of the internal hydrogen bond makes this transition state very apolar, and thus, quite insensitive to the polarity of the solvent. When computed in the gas phase (as the extreme case for an apolar environment), the Gibbs Free activation energy was as low as $14.6 \mathrm{kcal} / \mathrm{mol}$ for acetone derived enamine (TSA $\mathbf{M e}_{\mathbf{M e}} \mathbf{- R}$ ), and 20.3 $\mathrm{kcal} / \mathrm{mol}$ for the acetophenone (TSA $\mathbf{P h}-\mathbf{R})$. As expected, the energies in water are similar to the gas phase, increasing slightly to $15.3 \mathrm{kcal} / \mathrm{mol}$ for acetone, and staying $c a 20.0 \mathrm{kcal} / \mathrm{mol}$ for acetophenone.

A second main approach was found, wherein the nucleophile is attacking from the upper face of the enamine (Figure 3), in the distal position from the NHBoc group, and thus, without the possibility of forming any

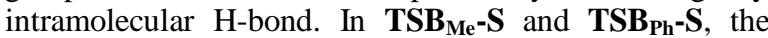
attack takes place from the left side (from our point of view in Figure 3) of the enamine, thorough the $\mathrm{Si}$ face of the nitroalkene ( $S$ product), whereas the approach of the nitroalkene from the right side of the enamine (hypothetical TSC) is strongly disfavoured due to steric repulsion with the large Boc group, which is blocking that face. We could not actually find any transition state for that approach without severely distorting the structure. Interestingly, the transition structures in Figure 3 are very polar, showing a clear separation of the developing positive and negative charges on the enamine and the nitroalkene, respectively. This type of situations are very sensitive to the environment, highly favoured in polar solvents, and specially in protic solvents (water) which are able to solvate and activate the electrophile by the formation of intermolecular H-bonds. Consequently, the computed energies in water $(16.9$ and $19.3 \mathrm{kcal} / \mathrm{mol})$ are lower than in the gas phase $(17.8$ and $21.7 \mathrm{kcal} / \mathrm{mol})$.

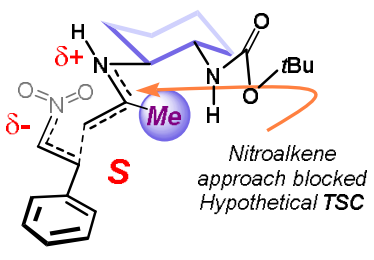

$\mathrm{TSB}_{\mathrm{Me}}-\mathrm{S}$

Acetone Si face approach gas phase: $17.8 \mathrm{kcal} / \mathrm{mol}$ water. $16.9 \mathrm{kcal} / \mathrm{mol}$

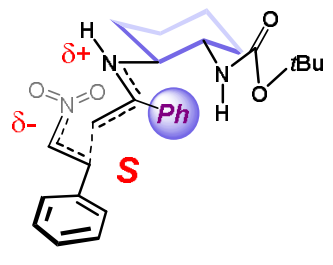

TSBPh-S

Acetophenone Si face approach gas phase: $21.7 \mathrm{kcal} / \mathrm{mol}$ water: $19.3 \mathrm{kcal} / \mathrm{mol}$
Figure 3. Computed Gibbs Free activation energies for the TSB-type transition states in the gas phase and water models.

Taking all together, these computational data are able to explain the experimental findings. If the reaction is performed in an apolar system, the lowest-in-energy transition states are $\mathbf{T S A} \mathbf{A}_{\mathbf{M e}}-\mathbf{R}$ and $\mathbf{T S A} \mathbf{A}_{\mathbf{P h}}-\mathbf{R}$, bearing the internal $\mathrm{H}$-bond activation, and explaining the highly enantioselective formation of the $R$ product. As the polarity of the solvent increases, the polar transition states (TSB-type, Figure 3) gain relative significance, inducing a deleterious effect on the enantioselectivity (Table 1, entries 8, 9 and 10). Furthermore, these results also agree with the common chemical sense, by which intramolecular H-bonds are stronger in apolar solvents, while intermolecular $\mathrm{H}$-bonds with surrounding water molecules are present in aqueous systems. Finally, 3D representations ${ }^{29}$ of the operative transition states for acetophenone in the gas phase and in the water model are shown in Figure 4. 

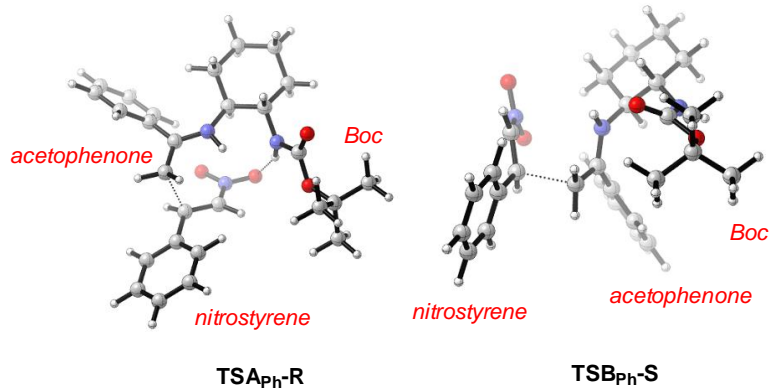

Figure 4. 3-D representation of the transition states for the reaction of acetophenone and nitrostyrene

\section{Conclusions}

We conclude that primary amine-containing carbamates, prepared easily by monoprotection of enantiomerically pure trans-cyclohexane-1,2-diamines with the common Boc, $\mathrm{Cbz}$ and Fmoc groups, act as organocatalysts in the enantioselective addition of aryl ketones to nitroalkenes, leading to enantiomerically enriched $\beta$-substituted $\gamma$-nitroketones. Good yields and enantioselectivities can be achieved working in the presence of 3,4-dimethoxybenzoic acid as additive. In addition, acetone can also be used as pro-nucleophile, although affording lower enantioselections. Theoretical calculations suggest that the presence of an intramolecular $\mathrm{H}$-bond activation of the nitrostyrene with the NHBoc moiety of the catalyst is responsible for the preferential formation of the $R$ product in apolar solvents like chloroform. The partial rupture of the $\mathrm{H}$-bond in polar solvents, like water or DMF, induces the formation of a more polar transition state ( $S$ enantiomer), explaining the deleterious effect of the solvent polarity on the enantioselectivity of the reaction.

\section{Experimental}

4.1. General. All the reagents and solvents were of the best grade available and used without further purification. IR data were collected with a Nicolet Impact 400D-FT spectrometer. The ${ }^{1} \mathrm{H}$ and ${ }^{13} \mathrm{C}$ NMR spectroscopic data were recorded at $25{ }^{\circ} \mathrm{C}$ with a Bruker AC-300 at 300 and $75 \mathrm{MHz}$, respectively, or a Bruker AC-400 at 400 and 101 $\mathrm{MHz}$, respectively, with TMS as the internal standard. MS spectra were registered with an Agilent MS 5973 (GC). HRMS analyses were performed with an Agilent 7200 Accurate-Mass Q-TOF instrument (DIP probe), using chemical ionization (methane). Nitroalkenes $\mathbf{5}$ were purchased or prepared according to a reported procedure, ${ }^{21}$ except $\mathbf{5 m}$ which was obtained following other methododology. ${ }^{22}$ Absolute configuration for adducts $\mathbf{6}$ was determined according to the described order of elution of their enantiomers in chiral HPLC, whereas in the case of new compounds it was assigned by analogy. In the case of compounds $6 \mathbf{b a}$ and 6on, the employed HPLC chiral columns are the same than those reported in the literature (Chiralpak AS-H and AD-H, respectively). It has been assured for the rest of the adducts that the employed Chiralpak AS-H column maintains the same elution order of the enantiomers than when using a Chiralpak AD-H column, but giving cleaner determinations in the reaction crude. Reference racemic samples of adducts $\mathbf{6}$ were obtained by performing the reaction using an equimolecular mixture of $\mathbf{1}$ and ent-1 $(20 \mathrm{~mol} \%)$ as organocatalyst in toluene as solvent at 25 ${ }^{\circ} \mathrm{C}$.

4.2. General Procedure for the Enantioselective Conjugate Addition Reaction. To a solution of 1 (8.6 $\mathrm{mg}, 0.04 \mathrm{mmol})$, the nitroalkene $(0.2 \mathrm{mmol})$ and $3,4-$ dimethoxybenzoic acid $(7.3 \mathrm{mg}, 0.04 \mathrm{mmol})$ in $\mathrm{CHCl}_{3}$ $(0.5 \mathrm{~mL})$ was added the ketone $(0.4 \mathrm{mmol}$ for $\mathbf{4 a - n}, 74$ $\mu \mathrm{L}, 1 \mathrm{mmol}$ for 40 ) and the mixture was stirred at $25^{\circ} \mathrm{C}$ for the time shown in Table 2. The reaction was quenched with $\mathrm{HCl} 2 \mathrm{~N}(10 \mathrm{~mL})$ and the mixture was extracted with AcOEt $(3 \times 10 \mathrm{~mL})$. The organic phase was dried over $\mathrm{MgSO}_{4}$, and the solvent was evaporated (15 Torr) to get the crude product, which was purified by silica gel chromatography ( $n$-hexane/AcOEt gradients).

Adducts 6 were identified by comparison of their spectroscopic data with those of the literature. Their enantiomeric excesses were determined by chiral HPLC.

(R)-4-nitro-1,3-diphenylbutan-2-one $\quad$ (6aa). ${ }^{16 \mathrm{c}}$ White solid, mp 88-89 ${ }^{\circ} \mathrm{C} ;{ }^{1} \mathrm{H} \mathrm{NMR}\left(300 \mathrm{MHz}, \mathrm{CDCl}_{3}\right): \delta_{H}=$ $7.92(\mathrm{dd}, J=8.4,1.3 \mathrm{~Hz}, 2 \mathrm{H}), 7.57$ (d, $J=7.4 \mathrm{~Hz}, 1 \mathrm{H})$, $7.46(\mathrm{dd}, J=8.2,6.9 \mathrm{~Hz}, 2 \mathrm{H}), 4.84(\mathrm{dd}, J=12.5,6.7 \mathrm{~Hz}$, $1 \mathrm{H}), 4.70(\mathrm{dd}, J=12.4,7.9 \mathrm{~Hz}, 1 \mathrm{H}), 4.29-4.17(\mathrm{~m}, 1 \mathrm{H})$, $3.50(\mathrm{dd}, J=16.3,5.0 \mathrm{~Hz}, 1 \mathrm{H}), 3.42(\mathrm{dd}, J=16.3,6.0 \mathrm{~Hz}$, 1H) ppm; 13C NMR (75 MHz, $\left.\mathrm{CDCl}_{3}\right): \delta_{C}=196.8$, 139.1, 136.4, 133.6, 129.1, 128.7, 128.0, 127.9, 127.4, 79.6, 41.5, 39.3 ppm; HPLC: Chiralpak AS-H, $\lambda=210$ $\mathrm{nm}, n$-hexane/2-propanol, 70:30, $1.0 \mathrm{~mL} / \min , \mathrm{t}_{\mathrm{r}}($ minor $)=$ 8.7 min, $\mathrm{t}_{\mathrm{r}}($ major $)=10.3 \mathrm{~min}$.

(R)-4-nitro-3-phenyl-1-(m-tolyl)butan-1-one $\quad$ (6ba). ${ }^{16 \mathrm{c}}$ Colourless oil; ${ }^{1} \mathrm{H}$ NMR $\left(300 \mathrm{MHz}, \mathrm{CDCl}_{3}\right): \delta_{H}=7.72-$ $7.70(\mathrm{~m}, 2 \mathrm{H}), 7.40-7.25(\mathrm{~m}, 7 \mathrm{H}), 4.81-4.86(\mathrm{dd}, J=6.8$ $\mathrm{Hz}, 12.8 \mathrm{~Hz}, 1 \mathrm{H}), 4.83$ (dd, $J=12.5,6.6 \mathrm{~Hz}, 1 \mathrm{H}), 4.68$ (dd, $J=12.5,8.1 \mathrm{~Hz}, 1 \mathrm{H}), 4.27-4.17(\mathrm{~m}, 1 \mathrm{H}), 3.47$ (dd, $J$ $=17.9,6.5 \mathrm{~Hz}, 1 \mathrm{H}), 3.40(\mathrm{dd}, J=17.9,7.7 \mathrm{~Hz}, 1 \mathrm{H}), 2.39$ (s, 3H) ppm; ${ }^{13} \mathrm{C}$ NMR (101 MHz, $\left.\mathrm{CDCl}_{3}\right): \delta_{C}=197.0$, $139.1,138.5,136.3,134.3,129.0,128.5,128.5,127.8$, 127.4, 125.2, 79.5, 41.5, 39.2, 21.3 ppm; HPLC: Chiralpak AS-H $, \lambda=210 \mathrm{~nm}, n$-hexane/2-propanol, $70: 30,1.0 \mathrm{~mL} / \mathrm{min}, \mathrm{t}_{\mathrm{r}}($ minor $)=7.2 \mathrm{~min}, \mathrm{t}_{\mathrm{r}}($ major $)=8.9$ min.

(R)-4-nitro-3-phenyl-1-(p-tolyl)butan-1-one $\quad$ (6ca). ${ }^{16 \mathrm{e}}$ Colourless oil; ${ }^{1} \mathrm{H}$ NMR $\left(300 \mathrm{MHz}, \mathrm{CDCl}_{3}\right): \delta_{H}=7.86-$ $7.78(\mathrm{~m}, 2 \mathrm{H}), 7.35-7.23(\mathrm{~m}, 7 \mathrm{H}), 4.83(\mathrm{dd}, J=12.5,6.5$ $\mathrm{Hz}, 1 \mathrm{H}), 4.67$ (dd, $J=12.5,8.1 \mathrm{~Hz}, 1 \mathrm{H}), 4.26-4.15(\mathrm{~m}$, $1 \mathrm{H}), 3.45$ (dd, $J=17.6,6.4 \mathrm{~Hz}, 1 \mathrm{H}), 3.37$ (dd, $J=17.6$, 
$7.6 \mathrm{~Hz}, 1 \mathrm{H}), 2.40(\mathrm{~s}, 3 \mathrm{H}) \mathrm{ppm} ;{ }^{13} \mathrm{C} \mathrm{NMR}(75 \mathrm{MHz}$, $\left.\mathrm{CDCl}_{3}\right): \delta_{C}=196.4,144.4,139.2,133.8,129.3,129.0$, 128.1, 127.8, 127.4, 79.5, 41.3, 39.3, 21.6 ppm; HPLC: Chiralpak AS-H $, \lambda=210 \mathrm{~nm}, n$-hexane/2-propanol, $70: 30,1.0 \mathrm{~mL} / \mathrm{min}, \mathrm{t}_{\mathrm{r}}($ minor $)=8.9 \mathrm{~min}, \mathrm{t}_{\mathrm{r}}($ major $)=10.5$ $\min$.

(R)-1-(4-methoxyphenyl)-4-nitro-3-phenylbutan-1-one (6da). ${ }^{16 \mathrm{c}}$ White solid, mp $90-91{ }^{\circ} \mathrm{C}$; ${ }^{1} \mathrm{H}$ NMR $(300 \mathrm{MHz}$, $\left.\mathrm{CDCl}_{3}\right): \delta_{H}=7.94(\mathrm{~d}, J=9.0 \mathrm{~Hz}, 4 \mathrm{H}), 7.38-7.23(\mathrm{~m}, 5 \mathrm{H})$, $6.93(\mathrm{~d}, J=8.9 \mathrm{~Hz}, 4 \mathrm{H}), 4.84(\mathrm{dd}, J=12.5,6.5 \mathrm{~Hz}, 1 \mathrm{H})$, 4.68 (dd, $J=12.5,8.1 \mathrm{~Hz}, 1 \mathrm{H}), 4.27-4.15$ (m, 1H), 3.87 (s, 3H), $3.43(\mathrm{dd}, J=17.5,6.4 \mathrm{~Hz}, 1 \mathrm{H}), 3.35$ (dd, $J=$ $17.5,7.6 \mathrm{~Hz}, 1 \mathrm{H}) \mathrm{ppm} ;{ }^{13} \mathrm{C} \mathrm{NMR}\left(75 \mathrm{MHz}, \mathrm{CDCl}_{3}\right): \delta_{C}=$ $195.3,163.8,139.3,130.3,129.4,129.00,127.8,127.4$, 113.8, 79.6, 55.5, 41.1, 39.4 ppm; HPLC: Chiralpak AS$\mathrm{H}, \lambda=210 \mathrm{~nm}, n$-hexane/2-propanol, 70:30, $1.0 \mathrm{~mL} / \mathrm{min}$, $\mathrm{t}_{\mathrm{r}}($ minor $)=18.9 \mathrm{~min}, \mathrm{t}_{\mathrm{r}}($ major $)=23.1 \mathrm{~min}$.

(R)-1-(4-fluorophenyl)-4-nitro-3-phenylbutan-1-one (6ea). ${ }^{23}$ Colourless oil; ${ }^{1} \mathrm{H}$ NMR $\left(300 \mathrm{MHz}, \mathrm{CDCl}_{3}\right): \delta_{H}=$ 7.98-7.93 (m, 2H), 7.37-3.32 (m, 2H), 7.31-7.24 (m, 3H), 7.16-7.10 (m, 2H), 4.83 (dd, $J=12.4,6.8 \mathrm{~Hz}, 1 \mathrm{H}), 4.69$ $(\mathrm{dd}, J=12.4,7.7 \mathrm{~Hz}, 1 \mathrm{H}), 4.27-4.17(\mathrm{~m}, 1 \mathrm{H}), 3.47$ (dd, $J$ $=17.7,6.6 \mathrm{~Hz}, 1 \mathrm{H}), 3.40(\mathrm{dd}, J=17.7,7.3 \mathrm{~Hz}, 1 \mathrm{H}) \mathrm{ppm}$; ${ }^{13} \mathrm{C}$ NMR $\left(75 \mathrm{MHz}, \mathrm{CDCl}_{3}\right): \delta_{C}=195.2,165.6(\mathrm{~d}, J=$ $254.6 \mathrm{~Hz}), 138.9,132.7(\mathrm{~d}, J=2.8 \mathrm{~Hz}), 130.8(\mathrm{~d}, J=9.3$ $\mathrm{Hz}), 129.0,127.8,127.3,115.5$ (d, $J=21.8 \mathrm{~Hz}), 79.4$, 41.3, 39.2 ppm; HPLC: Chiralpak AS-H , $\lambda=210 \mathrm{~nm}, n-$ hexane/2-propanol, 70:30, $1.0 \mathrm{~mL} / \mathrm{min}, \mathrm{t}_{\mathrm{r}}$ (minor) $=9.4$ $\min , \mathrm{t}_{\mathrm{r}}($ major $)=11.3 \mathrm{~min}$.

(R)-1-(3-chlorophenyl)-4-nitro-3-phenylbutan-1-one (6fa). ${ }^{16 \mathrm{e}}$ Colourless oil; ${ }^{1} \mathrm{H}$ NMR $\left(400 \mathrm{MHz}, \mathrm{CDCl}_{3}\right): \delta_{H}=$ 7.87 (t, $J=1.8 \mathrm{~Hz}, 1 \mathrm{H}$ ), 7.53 (ddd, $J=7.9,2.1,1.0 \mathrm{~Hz}$, $1 \mathrm{H}), 7.39(\mathrm{t}, J=7.9 \mathrm{~Hz}, 1 \mathrm{H}), 7.35-7.31(\mathrm{~m}, 2 \mathrm{H}), 7.30-$ $7.25(\mathrm{~m}, 3 \mathrm{H}), 4.80(\mathrm{dd}, \mathrm{J}=12.5,6.8 \mathrm{~Hz}, 1 \mathrm{H}), 4.68(\mathrm{dd}, J$ $=12.5,7.8 \mathrm{~Hz}, 1 \mathrm{H}), 4.25-4.17(\mathrm{~m}, 1 \mathrm{H}), 3.46(\mathrm{dd}, J=17.8$, $6.6 \mathrm{~Hz}, 1 \mathrm{H}), 3.40(\mathrm{dd}, J=17.8,7.2 \mathrm{~Hz}, 1 \mathrm{H}) \mathrm{ppm} ;{ }^{13} \mathrm{C}$ NMR $\left(101 \mathrm{MHz}, \mathrm{CDCl}_{3}\right): \delta_{C}=195.5,138.8,137.8,135.0$, $133.4,130.0,129.1,128.1,127.9,127.4,126.0,79.4$, 41.6, 39.1 ppm; HPLC: Chiralpak AS-H , $\lambda=210 \mathrm{~nm}, n-$ hexane/2-propanol, 70:30, $1.0 \mathrm{~mL} / \mathrm{min}, \mathrm{t}_{\mathrm{r}}$ (minor) $=8.5$ $\min , \mathrm{t}_{\mathrm{r}}($ major $)=10.6 \mathrm{~min}$.

(R)-1-(4-chlorophenyl)-4-nitro-3-phenylbutan-1-one (6ga). ${ }^{16 \mathrm{c}}$ White solid, mp 67-68 ${ }^{\circ} \mathrm{C} ;{ }^{1} \mathrm{H}$ NMR $(400 \mathrm{MHz}$, $\left.\mathrm{CDCl}_{3}\right): \delta_{H}=7.84(\mathrm{~d}, J=8.7 \mathrm{~Hz}, 1 \mathrm{H}), 7.41(\mathrm{~d}, J=8.7 \mathrm{~Hz}$, $1 \mathrm{H}), 7.35-7.31(\mathrm{~m}, 2 \mathrm{H}), 7.30-7.24(\mathrm{~m}, 3 \mathrm{H}), 4.81(\mathrm{dd}, J=$ $12.5,6.8 \mathrm{~Hz}, 1 \mathrm{H}), 4.68(\mathrm{dd}, J=12.5,7.8 \mathrm{~Hz}, 1 \mathrm{H}), 4.24-$ $4.17(\mathrm{~m}, 1 \mathrm{H}), 3.44(\mathrm{dd}, J=17.7,6.6 \mathrm{~Hz}, 1 \mathrm{H}), 3.39$ (dd, $J$ $=17.7,7.3 \mathrm{~Hz}, 1 \mathrm{H}) \mathrm{ppm} ;{ }^{13} \mathrm{C}$ NMR $\left(101 \mathrm{MHz}, \mathrm{CDCl}_{3}\right)$ : $\delta_{C}=195.6,140.00,138.9,134.6,129.4,129.1,129.0$, 127.9, 127.4, 79.4, 41.4, 39.2 ppm; HPLC: Chiralpak AS$\mathrm{H}, \lambda=210 \mathrm{~nm}, n$-hexane/2-propanol, 70:30, $1.0 \mathrm{~mL} / \mathrm{min}$, $\mathrm{t}_{\mathrm{r}}($ minor $)=10.5 \min , \mathrm{t}_{\mathrm{r}}($ major $)=12.6 \mathrm{~min}$.
(R)-1-(4-bromophenyl)-4-nitro-3-phenylbutan-1-one (6ha). ${ }^{16 \mathrm{e}}$ White solid, mp 86-87 ${ }^{\circ} \mathrm{C}$; ${ }^{1} \mathrm{H}$ NMR $(400 \mathrm{MHz}$, $\left.\mathrm{CDCl}_{3}\right): \delta_{H}=7.76(\mathrm{~d}, J=8.7 \mathrm{~Hz}, 1 \mathrm{H}), 7.58(\mathrm{~d}, J=8.7 \mathrm{~Hz}$, $1 \mathrm{H}), 7.36-7.29(\mathrm{~m}, 2 \mathrm{H}), 7.28-7.24(\mathrm{~m}, 3 \mathrm{H}), 4.81$ (dd, $J=$ $12.5,6.8 \mathrm{~Hz}, 1 \mathrm{H}), 4.68(\mathrm{dd}, J=12.5,7.8 \mathrm{~Hz}, 1 \mathrm{H}), 4.24-$ $4.17(\mathrm{~m}, 1 \mathrm{H}), 3.44(\mathrm{dd}, J=17.7,6.5 \mathrm{~Hz}, 1 \mathrm{H}), 3.38(\mathrm{dd}, J$ $=17.7,7.3 \mathrm{~Hz}, 1 \mathrm{H}) \mathrm{ppm} ;{ }^{13} \mathrm{C} \mathrm{NMR}\left(101 \mathrm{MHz}, \mathrm{CDCl}_{3}\right)$ : $\delta_{C}=195.8,138.8,135.0,132.0,129.5,129.1,128.8$, 127.9, 127.4, 79.4, 41.4, 39.2 ppm; HPLC: Chiralpak AS$\mathrm{H}, \lambda=210 \mathrm{~nm}, n$-hexane/2-propanol, 70:30, $1.0 \mathrm{~mL} / \mathrm{min}$, $\mathrm{t}_{\mathrm{r}}($ minor $)=11.8 \mathrm{~min}, \mathrm{t}_{\mathrm{r}}($ major $)=14.5 \mathrm{~min}$.

(R)-1-(4-iodophenyl)-4-nitro-3-phenylbutan-1-one (6ia). ${ }^{15 b}$ White solid, mp $98-99{ }^{\circ} \mathrm{C} ;{ }^{1} \mathrm{H}$ NMR $(300 \mathrm{MHz}$, $\left.\mathrm{CDCl}_{3}\right): \delta_{H}=7.81(\mathrm{~d}, J=8.7 \mathrm{~Hz}, 1 \mathrm{H}), 7.60(\mathrm{~d}, J=8.7 \mathrm{~Hz}$, $1 \mathrm{H}), 7.40-7.17(\mathrm{~m}, 5 \mathrm{H}), 4.80(\mathrm{dd}, J=12.5,6.8 \mathrm{~Hz}, 1 \mathrm{H})$, 4.67 (dd, $J=12.5,7.8 \mathrm{~Hz}, 1 \mathrm{H}), 4.25-4.15(\mathrm{~m}, 1 \mathrm{H}), 3.45$ $(\mathrm{dd}, J=17.7,6.6 \mathrm{~Hz}, 1 \mathrm{H}), 3.38(\mathrm{dd}, J=17.7,7.3 \mathrm{~Hz}, 1 \mathrm{H})$ ppm; ${ }^{13} \mathrm{C}$ NMR $\left(75 \mathrm{MHz}, \mathrm{CDCl}_{3}\right): \delta_{C}=196.1,138.8$, $138.0,135.5,129.3,129.1,127.9,127.4,101.6,79.4$, 41.3, 39.2 ppm; HPLC: Chiralpak AS-H , $\lambda=210 \mathrm{~nm}, n-$ hexane/2-propanol, 70:30, $1.0 \mathrm{~mL} / \mathrm{min}, \mathrm{t}_{\mathrm{r}}$ (minor) $=14.4$ $\min , \mathrm{t}_{\mathrm{r}}($ major $)=17.9 \mathrm{~min}$.

(R)-4-nitro-3-phenyl-1-(3-(trifluoromethyl)phenyl)butan-1-one (6ja). Colourless oil; IR (ATR): $v=3066$, 2922, 1690, 1550, 1409, 1321, 1167, 1126, $1065 \mathrm{~cm}^{-1} ;{ }^{1} \mathrm{H}$ NMR $\left(400 \mathrm{MHz}, \mathrm{CDCl}_{3}\right): \delta_{H}=8.10(\mathrm{~d}, J=7.9 \mathrm{~Hz}, 1 \mathrm{H})$, $7.83(\mathrm{~d}, J=7.9 \mathrm{~Hz}, 1 \mathrm{H}), 7.61(\mathrm{t}, J=7.8 \mathrm{~Hz}, 1 \mathrm{H}), 7.39$ $7.21(\mathrm{~m}, 5 \mathrm{H}), 4.83(\mathrm{dd}, J=12.5,7.0 \mathrm{~Hz}, 1 \mathrm{H}), 4.71(\mathrm{dd}, J$ $=12.5,7.6 \mathrm{~Hz}, 1 \mathrm{H}), 4.28-4.21(\mathrm{~m}, 1 \mathrm{H}), 3.52(\mathrm{dd}, J=17.8$, $6.6 \mathrm{~Hz}, 1 \mathrm{H}), 3.46(\mathrm{dd}, J=17.8,7.1 \mathrm{~Hz}, 1 \mathrm{H}) \mathrm{ppm} ;{ }^{13} \mathrm{C}$ NMR $\left(101 \mathrm{MHz}, \mathrm{CDCl}_{3}\right): \delta_{C}=195.5,138.7,136.8,131.4$ $(\mathrm{q}, J=33.3 \mathrm{~Hz}), 131.12,129.9(\mathrm{q}, J=3.4 \mathrm{~Hz}), 129.5$, $129.2,128.0,127.4,124.8(\mathrm{q}, J=3.9 \mathrm{~Hz}), 123.5(\mathrm{q}, J=$ 273.7Hz), 79.4, 41.6, $39.2 \mathrm{ppm}$; MS (EI, $70 \mathrm{ev}): \mathrm{m} / \mathrm{z}(\%)$ = 287 (100), 275 (46), 185 (54), 173 (28), 145 (41), 130 (17), 103 (21), 77 (15); HRMS $\left(\mathrm{CI}-\mathrm{CH}_{4}\right): \mathrm{m} / \mathrm{z}$ calcd for $\mathrm{C}_{17} \mathrm{H}_{15} \mathrm{~F}_{3} \mathrm{NO}_{3} \quad[\mathrm{M}+\mathrm{H}]^{+}:$338,0999, found: 338.1005; HPLC: Chiralpak AS-H , $\lambda=210 \mathrm{~nm}, \quad n$-hexane/2propanol, 80:20, $1.0 \mathrm{~mL} / \mathrm{min}, \mathrm{t}_{\mathrm{r}}($ minor $)=7.8 \mathrm{~min}, \mathrm{t}_{\mathrm{r}}$ (major) $=9.7 \mathrm{~min}$.

(R)-4-nitro-3-phenyl-1-(4-(trifluoromethyl)phenyl)butan-1-one (6ka). ${ }^{16 \mathrm{~g}}$ Colourless oil; ${ }^{1} \mathrm{H}$ NMR (300 $\left.\mathrm{MHz}, \mathrm{CDCl}_{3}\right): \delta_{H}=8.00(\mathrm{~d}, J=8.2 \mathrm{~Hz}, 2 \mathrm{H}), 7.71(\mathrm{~d}, J=$ $8.2 \mathrm{~Hz}, 2 \mathrm{H}), 7.37-7.17(\mathrm{~m}, 5 \mathrm{H}), 4.81(\mathrm{dd}, J=12.5,7.0$ $\mathrm{Hz}, 1 \mathrm{H}), 4.69(\mathrm{dd}, J=12.5,7.6 \mathrm{~Hz}, 1 \mathrm{H}), 4.27-4.18(\mathrm{~m}$, $1 \mathrm{H}), 3.51$ (dd, $J=17.9,6.7 \mathrm{~Hz}, 1 \mathrm{H}), 3.45$ (dd, $J=17.9$, $7.1 \mathrm{~Hz}, 1 \mathrm{H}) \mathrm{ppm} ;{ }^{13} \mathrm{C} \mathrm{NMR}\left(75 \mathrm{MHz}, \mathrm{CDCl}_{3}\right): \delta_{C}=$ $195.9,139.0,138.7,134.7(\mathrm{q}, J=32.7 \mathrm{~Hz}), 129.1,128.3$, 128.0, 127.4, 125.7 (q, $J=3.6 \mathrm{~Hz}), 123.4$ (q, $J=272.9$ Hz), 79.4, 41.8, 39.2 ppm; HPLC: Chiralpak AS-H, $\lambda=$ $210 \mathrm{~nm}, \quad n$-hexane/2-propanol, 70:30, $1.0 \mathrm{~mL} / \mathrm{min}, \mathrm{t}_{\mathrm{r}}$ $($ minor $)=7.1 \mathrm{~min}, \mathrm{t}_{\mathrm{r}}($ major $)=8.4 \mathrm{~min}$.

(R)-4-nitro-1-(4-nitrophenyl)-3-phenylbutan-1-one (6la). ${ }^{16 \mathrm{~g}}$ Pale yellow solid, mp $91-92{ }^{\circ} \mathrm{C}$; ${ }^{1} \mathrm{H}$ NMR (400 
$\left.\mathrm{MHz}, \mathrm{CDCl}_{3}\right): \delta_{H}=8.28(\mathrm{~d}, J=8.9 \mathrm{~Hz}, 1 \mathrm{H}), 8.05(\mathrm{~d}, J=$ $8.9 \mathrm{~Hz}, 1 \mathrm{H}), 7.37-7.31(\mathrm{~m}, 2 \mathrm{H}), 7.31-7.24(\mathrm{~m}, 3 \mathrm{H}), 4.81$ (dd, $J=12.5,7.1 \mathrm{~Hz}, 1 \mathrm{H}), 4.71(\mathrm{dd}, J=12.5,7.5 \mathrm{~Hz}, 1 \mathrm{H})$, 4.26-4.19 (m, 1H), 3.55 (dd, $J=17.8,6.7 \mathrm{~Hz}, 1 \mathrm{H}), 3.50$ $(\mathrm{dd}, J=17.8,7.0 \mathrm{~Hz}, 1 \mathrm{H}) \mathrm{ppm} ;{ }^{13} \mathrm{C} \mathrm{NMR}(101 \mathrm{MHz}$, $\left.\mathrm{CDCl}_{3}\right): \delta_{C}=195.4,140.6,138.5,129.1,129.0,128.0$, 127.3, 123.9, 79.3, 42.0, 39.1 ppm; HPLC: Chiralpak AS$\mathrm{H}, \lambda=210 \mathrm{~nm}, n$-hexane/2-propanol, 70:30, $1.0 \mathrm{~mL} / \mathrm{min}$, $\mathrm{t}_{\mathrm{r}}($ minor $)=32.8$ min, $\mathrm{t}_{\mathrm{r}}($ major $)=36.7 \mathrm{~min}$.

(R)-1-(naphthalen-2-yl)-4-nitro-3-phenylbutan-1-one (6ma). ${ }^{15 \mathrm{~b}}$ White solid, mp 78-79 ${ }^{\circ} \mathrm{C} ;{ }^{1} \mathrm{H}$ NMR (400 MHz, $\left.\mathrm{CDCl}_{3}\right): \delta_{H}=8.41(\mathrm{~s}, 1 \mathrm{H}), 7.96(\mathrm{dd}, J=8.7,1.6 \mathrm{~Hz}, 1 \mathrm{H})$, $7.93(\mathrm{~d}, J=8.1 \mathrm{~Hz}, 1 \mathrm{H}), 7.86(\mathrm{dd}, J=8.1,4.1 \mathrm{~Hz}, 2 \mathrm{H})$, 7.62-7.52 (m, 2H), 7.38- 7.29 (m, 4H), 7.28-7.25 (m, 1H), $4.87(\mathrm{dd}, J=12.5,6.6 \mathrm{~Hz}, 1 \mathrm{H}), 4.72(\mathrm{dd}, J=12.5,8.0 \mathrm{~Hz}$, $1 \mathrm{H}), 4.32-4.24$ (m, 1H), 3.60 (dd, $J=18.3,7.1 \mathrm{~Hz}, 1 \mathrm{H})$, $3.54(\mathrm{dd}, J=18.3,8.2 \mathrm{~Hz}, 1 \mathrm{H}) \mathrm{ppm} ;{ }^{13} \mathrm{C}$ NMR $(101 \mathrm{MHz}$, $\left.\mathrm{CDCl}_{3}\right): \delta_{C}=196.7,139.1,135.7,133.6,132.4,129.8$, $129.5,129.0,128.7,128.6,127.8,127.6,127.4,126.9$, 123.5, 79.6, 41.5, 39.4 ppm; HPLC: Chiralpak AS-H , $\lambda=$ $210 \mathrm{~nm}, n$-hexane/2-propanol, 70:30, $1.0 \mathrm{~mL} / \mathrm{min}, \mathrm{t}_{\mathrm{r}}$ $($ minor $)=10.6 \min , \mathrm{t}_{\mathrm{r}}($ major $)=11.9 \min$.

(R)-4-nitro-3-phenyl-1-(pyridin-2-yl)butan-1-one (6na). ${ }^{24}$ White solid, mp 59-61 ${ }^{\circ} \mathrm{C} ;{ }^{1} \mathrm{H}$ NMR (400 MHz, $\left.\mathrm{CDCl}_{3}\right): \delta_{H}=8.65(\mathrm{ddd}, J=4.8,1.7,0.9 \mathrm{~Hz}, 1 \mathrm{H}), 7.98$ $(\mathrm{dt}, J=7.7,0.9 \mathrm{~Hz}, 1 \mathrm{H}), 7.80(\mathrm{td}, J=7.7,1.7 \mathrm{~Hz}, 1 \mathrm{H})$, 7.46 (ddd, $J=7.7,4.8,0.9 \mathrm{~Hz}, 1 \mathrm{H}), 7.34-7.28(\mathrm{~m}, 4 \mathrm{H})$, 7.27-7.19 (m, 1H), 4.79 (dd, $J=12.4,6.7 \mathrm{~Hz}, 1 \mathrm{H}), 4.68$ (dd, $J=12.4,8.3 \mathrm{~Hz}, 1 \mathrm{H}), 4.28-4.21(\mathrm{~m}, 1 \mathrm{H}), 3.83$ (dd, $J$ $=18.2,7.0 \mathrm{~Hz}, 1 \mathrm{H}), 3.62(\mathrm{dd}, J=18.2,7.2 \mathrm{~Hz}, 1 \mathrm{H}) \mathrm{ppm}$; ${ }^{13} \mathrm{C}$ NMR $\left(101 \mathrm{MHz}, \mathrm{CDCl}_{3}\right): \delta_{C}=198.5,152.6,148.9$, 139.2, 136.9, 128.9, 127.6, 127.5, 121.8, 79.8, 40.7, 39.2 ppm; HPLC: Chiralpak AS-H, $\lambda=210 \mathrm{~nm}, n$-hexane/2propanol, 70:30, $1.0 \mathrm{~mL} / \mathrm{min}, \mathrm{t}_{\mathrm{r}}$ (minor) $=8.5 \mathrm{~min}, \mathrm{t}_{\mathrm{r}}$ $($ major $)=9.4 \mathrm{~min}$.

(R)-4-nitro-1-phenyl-3-(p-tolyl)butan-1-one $\quad(6 \mathbf{a b}) .{ }^{16 \mathrm{c}}$ White solid, mp 72-73 ${ }^{\circ} \mathrm{C} ;{ }^{1} \mathrm{H}$ NMR (400 MHz, $\mathrm{CDCl}_{3}$ ): $\delta_{H}=7.94-7.88(\mathrm{~m}, 2 \mathrm{H}), 7.60-7.52(\mathrm{~m}, 1 \mathrm{H}), 7.48-7.41(\mathrm{~m}$, 2H), 7.19-7.09 (m, 4H), $4.80(\mathrm{dd}, J=12.4,6.6 \mathrm{~Hz}, 1 \mathrm{H})$, $4.65(\mathrm{dd}, J=12.4,8.0 \mathrm{~Hz}, 1 \mathrm{H}), 4.22-4.14(\mathrm{~m}, 1 \mathrm{H}), 3.45$ (dd, $J=17.6,6.4 \mathrm{~Hz}, 1 \mathrm{H}), 3.39$ (dd, $J=17.6,7.4 \mathrm{~Hz}, 1 \mathrm{H})$, $2.30(\mathrm{~s}, 3 \mathrm{H}) \mathrm{ppm} ;{ }^{13} \mathrm{C}$ NMR $\left(101 \mathrm{MHz}, \mathrm{CDCl}_{3}\right): \delta_{C}=$ $196.9,137.5,136.3,136.0,133.5,129.7,128.7,128.0$, 127.2, 79.7, 41.5, 38.9, 21.0 ppm; HPLC: Chiralpak AS$\mathrm{H}, \lambda=210 \mathrm{~nm}, n$-hexane/2-propanol, 70:30, $1.0 \mathrm{~mL} / \mathrm{min}$, $\mathrm{t}_{\mathrm{r}}($ minor $)=7.9 \mathrm{~min}, \mathrm{t}_{\mathrm{r}}($ major $)=10.1 \mathrm{~min}$.

(R)-3-(4-methoxyphenyl)-4-nitro-1-phenylbutan-1-one (6ac). ${ }^{16 \mathrm{c}}$ White solid, mp 69-70 ${ }^{\circ} \mathrm{C} ;{ }^{1} \mathrm{H}$ NMR $(400 \mathrm{MHz}$, $\left.\mathrm{CDCl}_{3}\right): \delta_{H}=7.96-7.85(\mathrm{~m}, 2 \mathrm{H}), 7.63-7.52(\mathrm{~m}, 1 \mathrm{H}), 7.47-$ $7.41(\mathrm{~m}, 2 \mathrm{H}), 7.20(\mathrm{~d}, J=8.7 \mathrm{~Hz}, 2 \mathrm{H}), 6.85(\mathrm{~d}, J=8.7$ $\mathrm{Hz}, 2 \mathrm{H}), 4.79(\mathrm{dd}, J=12.3,6.6 \mathrm{~Hz}, 1 \mathrm{H}), 4.64(\mathrm{dd}, J=$ 12.3, $8.0 \mathrm{~Hz}, 1 \mathrm{H}), 4.21-4.14(\mathrm{~m}, 1 \mathrm{H}), 3.77(\mathrm{~s}, 1 \mathrm{H}), 3.45$ $(\mathrm{dd}, J=17.6,6.5 \mathrm{~Hz}, 1 \mathrm{H}), 3.39(\mathrm{dd}, J=17.6,7.3 \mathrm{~Hz}, 1 \mathrm{H})$ ppm; ${ }^{13} \mathrm{C}$ NMR (101 MHz, $\left.\mathrm{CDCl}_{3}\right): \delta_{C}=196.9,159.0$,
$136.4,133.5,130.9,128.7,128.5,128.0,114.4,79.8$, 55.2, 41.6, 38.6 ppm; HPLC: Chiralpak AS-H, $\lambda=210$ $\mathrm{nm}, n$-hexane/2-propanol, 70:30, $1.0 \mathrm{~mL} / \mathrm{min}, \mathrm{t}_{\mathrm{r}}$ (minor) $=$ $14.6 \mathrm{~min}, \mathrm{t}_{\mathrm{r}}$ (major) $=17.6 \mathrm{~min}$.

(R)-3-(benzo[d][1,3]dioxol-5-yl)-4-nitro-1-phenylbutan-1-one (6ad). ${ }^{23}$ White solid, mp $82-83{ }^{\circ} \mathrm{C}$; ${ }^{1} \mathrm{H}$ NMR (400 MHz, $\left.\mathrm{CDCl}_{3}\right): \delta_{H}=7.94-7.91(\mathrm{~m}, 2 \mathrm{H}), 7.61-7.54(\mathrm{~m}$, $1 \mathrm{H}), 7.50-7.43(\mathrm{~m}, 2 \mathrm{H}), 6.76(\mathrm{~d}, J=1.1 \mathrm{~Hz}, 1 \mathrm{H}), 6.74(\mathrm{~d}$, $J=1.3 \mathrm{~Hz}, 2 \mathrm{H}), 5.93(\mathrm{~s}, 2 \mathrm{H}), 4.78(\mathrm{dd}, J=12.4,6.5 \mathrm{~Hz}$, $1 \mathrm{H}), 4.62(\mathrm{dd}, J=12.4,8.1 \mathrm{~Hz}, 1 \mathrm{H}), 4.18-4.11(\mathrm{~m}, 1 \mathrm{H})$, $3.44(\mathrm{dd}, J=17.6,6.5 \mathrm{~Hz}, 1 \mathrm{H}), 3.37$ (dd, $J=17.6,7.4 \mathrm{~Hz}$, 1H) ppm; ${ }^{13} \mathrm{C}$ NMR (101 $\left.\mathrm{MHz}, \mathrm{CDCl}_{3}\right): \delta_{C}=196.8$, $148.1,147.1,136.3,133.6,132.7,128.7,128.0,120.7$, 108.7, 107.7, 101.2, 79.7, 41.6, 39.1 ppm; HPLC: Chiralpak AS-H $, \lambda=210 \mathrm{~nm}, n$-hexane/2-propanol, $70: 30,1.0 \mathrm{~mL} / \mathrm{min}, \mathrm{t}_{\mathrm{r}}($ minor $)=20.0 \mathrm{~min}, \mathrm{t}_{\mathrm{r}}$ (major) $=$ $25.9 \mathrm{~min}$.

(R)-4-nitro-1-phenyl-3-(3,4,5-trimethoxyphenyl)butan1-one (6ae). ${ }^{16 \mathrm{f}}$ White solid, mp 142-143 ${ }^{\circ} \mathrm{C} ;{ }^{1} \mathrm{H}$ NMR (300 MHz, $\left.\mathrm{CDCl}_{3}\right): \delta_{H}=7.95-7.90(\mathrm{~m}, 2 \mathrm{H}), 7.63-7.54(\mathrm{~m}$, $1 \mathrm{H}), 7.50-7.42(\mathrm{~m}, 2 \mathrm{H}), 4.83(\mathrm{dd}, J=12.5,6.6 \mathrm{~Hz}, 1 \mathrm{H})$, 4.69 (dd, $J=12.5,8.0 \mathrm{~Hz}, 1 \mathrm{H}), 4.23-4.12(\mathrm{~m}, 1 \mathrm{H}), 3.84$ (s, 6H), $3.81(\mathrm{~s}, 3 \mathrm{H}), 3.47(\mathrm{dd}, J=17.6,6.3 \mathrm{~Hz}, 1 \mathrm{H}), 3.38$ $(\mathrm{dd}, J=17.6,7.5 \mathrm{~Hz}, 1 \mathrm{H}) \mathrm{ppm} ;{ }^{13} \mathrm{C} \mathrm{NMR}(75 \mathrm{MHz}$, $\left.\mathrm{CDCl}_{3}\right): \delta_{C}=196.9,153.5,137.6,136.4,134.7,133.6$, 128.7, 128.0, 104.6, 79.4, 60.7, 56.2, 41.6, 39.6 ppm; HPLC: Chiralpak AS-H $, \lambda=210 \mathrm{~nm}, \quad n$-hexane/2propanol, 80:20, $1.0 \mathrm{~mL} / \mathrm{min}, \mathrm{t}_{\mathrm{r}}($ minor $)=14.9 \mathrm{~min}, \mathrm{t}_{\mathrm{r}}$ $($ major $)=17.1 \mathrm{~min}$.

(R)-3-(4-fluorophenyl)-4-nitro-1-phenylbutan-1-one (6af). ${ }^{16 \mathrm{~h}}$ Colourless oil; ${ }^{1} \mathrm{H} \mathrm{NMR}\left(400 \mathrm{MHz}, \mathrm{CDCl}_{3}\right): \delta_{H}=$ 7.95-7.87 (m, 2H), 7.62-7.54 (m, 1H), 7.49-7.42 (m, 2H), $7.30-7.23(\mathrm{~m}, 2 \mathrm{H}), 7.02(\mathrm{t}, J=8.7 \mathrm{~Hz}, 2 \mathrm{H}), 4.82(\mathrm{dd}, J=$ $12.5,6.5 \mathrm{~Hz}, 1 \mathrm{H}), 4.66$ (dd, $J=12.5,8.2 \mathrm{~Hz}, 1 \mathrm{H}), 4.26-$ $4.19(\mathrm{~m}, 1 \mathrm{H}), 3.46(\mathrm{dd}, J=17.7,6.7 \mathrm{~Hz}, 1 \mathrm{H}), 3.41(\mathrm{dd}, J$ $=17.7,7.3 \mathrm{~Hz}, 1 \mathrm{H}) \mathrm{ppm} ;{ }^{13} \mathrm{C} \mathrm{NMR}\left(101 \mathrm{MHz}, \mathrm{CDCl}_{3}\right)$ : $\delta_{C}=196.6,162.1(\mathrm{~d}, J=246.6 \mathrm{~Hz}), 136.2,134.8(\mathrm{~d}, J=$ $3.2 \mathrm{~Hz}), 133.6,129.1$ (d, $J=8.1 \mathrm{~Hz}), 128.7,128.0,115.9$ $(\mathrm{d}, J=21.5 \mathrm{~Hz}), 79.5,41.5,38.6$ ppm; HPLC: Chiralpak AS-H $, \lambda=210 \mathrm{~nm}, n$-hexane/2-propanol, $70: 30,1.0 \mathrm{~mL} / \mathrm{min}, \mathrm{t}_{\mathrm{r}}($ minor $)=9.6 \mathrm{~min}, \mathrm{t}_{\mathrm{r}}($ major $)=11.1$ $\min$.

(R)-3-(2-chlorophenyl)-4-nitro-1-phenylbutan-1-one (6ag). ${ }^{16 \mathrm{c}}$ Colourless oil; ${ }^{1} \mathrm{H} \mathrm{NMR}\left(400 \mathrm{MHz}, \mathrm{CDCl}_{3}\right): \delta_{H}$ $=7.94(\mathrm{dd}, J=8.4,1.3 \mathrm{~Hz}, 2 \mathrm{H}), 7.62-7.54(\mathrm{~m}, 1 \mathrm{H}), 7.49-$ $7.43(\mathrm{~m}, 2 \mathrm{H}), 7.43-7.39(\mathrm{~m}, 1 \mathrm{H}), 7.31-7.27(\mathrm{~m}, 1 \mathrm{H}), 7.27-$ $7.18(\mathrm{~m}, 2 \mathrm{H}), 4.89(\mathrm{dd}, J=12.8,6.9 \mathrm{~Hz}, 1 \mathrm{H}), 4.85(\mathrm{dd}, J$ $=12.8,6.7,1 \mathrm{H}), 4.72-66(\mathrm{~m}, 1 \mathrm{H}), 3.58(\mathrm{dd}, J=17.9,7.4$ $\mathrm{Hz}, 1 \mathrm{H}), 3.52$ (dd, $J=17.9,6.4 \mathrm{~Hz}, 1 \mathrm{H}) \mathrm{ppm} ;{ }^{13} \mathrm{C} \mathrm{NMR}$ $\left(101 \mathrm{MHz}, \mathrm{CDCl}_{3}\right): \delta_{C}=196.7,136.2,133.7,133.6$, 130.4, 129.0, 128.7, 128.4, 128.0, 127.3, 77.5, 39.8, 36.1 ppm; HPLC: Chiralpak AS-H, $\lambda=210 \mathrm{~nm}, n$-hexane/2propanol, 70:30, $1.0 \mathrm{~mL} / \mathrm{min}, \mathrm{t}_{\mathrm{r}}($ minor $)=8.3 \mathrm{~min}, \mathrm{t}_{\mathrm{r}}$ (major) $=9.4 \mathrm{~min}$. 
(R)-3-(4-chlorophenyl)-4-nitro-1-phenylbutan-1-one (6ah). ${ }^{16 \mathrm{c}}$ White solid, mp $48-49{ }^{\circ} \mathrm{C}$; ${ }^{1} \mathrm{H}$ NMR (400 MHz, $\left.\mathrm{CDCl}_{3}\right): \delta_{H}=7.91(\mathrm{dd}, J=8.4,1.3 \mathrm{~Hz}, 2 \mathrm{H}), 7.62-7.55(\mathrm{~m}$, $1 \mathrm{H}), 7.50-7.44(\mathrm{~m}, 2 \mathrm{H}), 7.30(\mathrm{~d}, J=8.4 \mathrm{~Hz}, 2 \mathrm{H}), 7.27$ $7.21(\mathrm{~m}, 2 \mathrm{H}), 4.81(\mathrm{dd}, J=12.6,6.5 \mathrm{~Hz}, 1 \mathrm{H}), 4.66(\mathrm{dd}, J$ $=12.6,8.2 \mathrm{~Hz}, 1 \mathrm{H}), 4.25-4.18(\mathrm{~m}, 1 \mathrm{H}), 3.46(\mathrm{dd}, J=17.8$, $6.7 \mathrm{~Hz}, 1 \mathrm{H}), 3.40(\mathrm{dd}, J=17.8,7.2 \mathrm{~Hz}, 1 \mathrm{H}) \mathrm{ppm} ;{ }^{13} \mathrm{C}$ NMR $\left(101 \mathrm{MHz}, \mathrm{CDCl}_{3}\right): \delta_{C}=196.4,137.6,136.2,133.7$, 129.2, 128.8, 128.7, 128.0, 79.3, 41.3, 38.6 ppm; HPLC: Chiralpak AS-H $, \lambda=210 \mathrm{~nm}, n$-hexane/2-propanol, $70: 30,1.0 \mathrm{~mL} / \mathrm{min}, \mathrm{t}_{\mathrm{r}}($ minor $)=9.4$ min, $\mathrm{t}_{\mathrm{r}}($ major $)=11.7$ $\min$.

(R)-3-(4-bromophenyl)-4-nitro-1-phenylbutan-1-one (6ai). ${ }^{16 \mathrm{e}}$ White solid, mp 66-67 ${ }^{\circ} \mathrm{C} ;{ }^{1} \mathrm{H}$ NMR $(400 \mathrm{MHz}$, $\left.\mathrm{CDCl}_{3}\right): \delta_{H}=7.90(\mathrm{~d}, J=8.4 \mathrm{~Hz}, 2 \mathrm{H}), 7.61-7.55(\mathrm{~m}, 1 \mathrm{H})$, $7.49-7.41(\mathrm{~m}, 4 \mathrm{H}), 7.17(\mathrm{~d}, J=8.4 \mathrm{~Hz}, 2 \mathrm{H}), 4.81(\mathrm{dd}, J=$ $12.6,6.4 \mathrm{~Hz}, 1 \mathrm{H}), 4.65$ (dd, $J=12.6,8.2 \mathrm{~Hz}, 1 \mathrm{H}), 4.23$ $4.16(\mathrm{~m}, 1 \mathrm{H}), 3.45(\mathrm{dd}, J=17.8,6.7 \mathrm{~Hz}, 1 \mathrm{H}), 3.40(\mathrm{dd}, J$ $=17.8,7.2 \mathrm{~Hz}, 1 \mathrm{H}) \mathrm{ppm} ;{ }^{13} \mathrm{C}$ NMR $\left(101 \mathrm{MHz}, \mathrm{CDCl}_{3}\right)$ : $\delta_{C}=196.4,138.1,136.1,133.7,132.1,129.2,128.7$, 127.9, 121.7, 79.2, 41.2, 38.7 ppm; HPLC: Chiralpak AS$\mathrm{H}, \lambda=210 \mathrm{~nm}, n$-hexane/2-propanol, 70:30, $1.0 \mathrm{~mL} / \mathrm{min}$, $\mathrm{t}_{\mathrm{r}}($ minor $)=9.8 \mathrm{~min}, \mathrm{t}_{\mathrm{r}}($ major $)=12.7 \mathrm{~min}$.

(R)-4-nitro-1-phenyl-3-(4-(trifluoromethyl)phenyl)butan-1-one (6aj). ${ }^{16 \mathrm{~g}}$ Colourless oil; ${ }^{1} \mathrm{H}$ NMR $(300 \mathrm{MHz}$, $\left.\mathrm{CDCl}_{3}\right): \delta_{H}=7.93-7.89(\mathrm{~m}, 2 \mathrm{H}), 7.61-7.58(\mathrm{~m}, 3 \mathrm{H}), 7.49$ $7.42(\mathrm{~m}, 4 \mathrm{H}), 4.86$ (dd, $J=12.7,6.4 \mathrm{~Hz}, 1 \mathrm{H}), 4.71$ (dd, $J$ $=12.7,8.2 \mathrm{~Hz}, 1 \mathrm{H}), 3.51(\mathrm{dd}, J=17.9,6.7 \mathrm{~Hz}, 1 \mathrm{H}), 3.44$ $(\mathrm{dd}, J=17.9,7.2 \mathrm{~Hz}, 1 \mathrm{H}) \mathrm{ppm} ;{ }^{13} \mathrm{C} \mathrm{NMR}(75 \mathrm{MHz}$, $\left.\mathrm{CDCl}_{3}\right): \delta_{C}=196.3,143.2,136.1,133.8,130.15$ (q, $J=$ $32.8 \mathrm{~Hz}), 128.8,128.0,126.34,126.0(\mathrm{q}, J=3.8 \mathrm{~Hz})$, 123.85 (q, $J=272.1 \mathrm{~Hz}), 79.0,41.2,39.0$ ppm; HPLC: Chiralpak AS-H $, \lambda=210 \mathrm{~nm}, n$-hexane/2-propanol, $70: 30,1.0 \mathrm{~mL} / \mathrm{min}, \mathrm{t}_{\mathrm{r}}($ minor $)=6.7 \mathrm{~min}, \mathrm{t}_{\mathrm{r}}$ (major) $=8.0$ $\min$.

\section{(R)-4-nitro-3-(4-nitrophenyl)-1-phenylbutan-1-one} (6ak). ${ }^{16 \mathrm{~h}}$ White solid, mp 102-103 ${ }^{\circ} \mathrm{C} ;{ }^{1} \mathrm{H}$ NMR (300 $\left.\mathrm{MHz}, \mathrm{CDCl}_{3}\right): \delta_{H}=8.25-8.18(\mathrm{~m}, 2 \mathrm{H}), 7.94-7.88(\mathrm{~m}, 2 \mathrm{H})$, 7.63-7.56 (m, 1H), 7.53-7.40 (m, 4H), 4.89 (dd, $J=12.9$, $6.2 \mathrm{~Hz}, 1 \mathrm{H}), 4.75(\mathrm{dd}, J=12.9,8.3 \mathrm{~Hz}, 1 \mathrm{H}), 4.43-4.35$ $(\mathrm{m}, 1 \mathrm{H}), 3.54(\mathrm{dd}, J=18.0,6.8 \mathrm{~Hz}, 1 \mathrm{H}), 3.47(\mathrm{dd}, J=$ 18.0, 7.0 Hz, 1H) ppm; ${ }^{13} \mathrm{C} \mathrm{NMR}\left(75 \mathrm{MHz}, \mathrm{CDCl}_{3}\right): \delta_{C}=$ $195.9,147.4,146.6,135.9,133.9,128.8,128.6,128.0$, 124.2, 78.8, 41.0, 38.9 ppm; HPLC: Chiralpak AD-H , $\lambda=$ $210 \mathrm{~nm}, n$-hexane/2-propanol, 80:20, $1.0 \mathrm{~mL} / \mathrm{min}, \mathrm{t}_{\mathrm{r}}$ $($ minor $)=22.2 \mathrm{~min}, \mathrm{t}_{\mathrm{r}}($ major $)=36.5 \mathrm{~min}$.

(R)-3-(naphthalen-2-yl)-4-nitro-1-phenylbutan-1-one (6al). ${ }^{16 \mathrm{c}}$ White solid, mp 89-90 ${ }^{\circ} \mathrm{C} ;{ }^{1} \mathrm{H}$ NMR (400 MHz, $\left.\mathrm{CDCl}_{3}\right): \delta_{H}=7.91(\mathrm{dd}, J=8.4,1.3 \mathrm{~Hz}, 2 \mathrm{H}), 7.85-7.74(\mathrm{~m}$, $3 \mathrm{H}), 7.72(\mathrm{~d}, J=1.3 \mathrm{~Hz}, 1 \mathrm{H}), 7.58-7.51(\mathrm{~m}, 1 \mathrm{H}), 7.51-$ $7.35(\mathrm{~m}, 5 \mathrm{H}), 4.89(\mathrm{dd}, J=12.5,6.6 \mathrm{~Hz}, 1 \mathrm{H}), 4.76(\mathrm{dd}, J$ $=12.5,8.0 \mathrm{~Hz}, 1 \mathrm{H}), 4.43-4.35(\mathrm{~m}, 1 \mathrm{H}), 3.56(\mathrm{dd}, J=17.7$, $6.4 \mathrm{~Hz}, 1 \mathrm{H}), 3.49(\mathrm{dd}, J=17.7,7.5 \mathrm{~Hz}, 1 \mathrm{H}) \mathrm{ppm} ;{ }^{13} \mathrm{C}$
NMR $\left(101 \mathrm{MHz}, \mathrm{CDCl}_{3}\right): \delta_{C}=196.7,136.5,136.3,133.5$, $133.3,132.8,128.9,128.7,128.0,127.8,127.6,126.5$, 126.4, 126.2, 125.1, 79.5, 41.5, 39.4 ppm; HPLC: Chiralpak AS-H $, \lambda=210 \mathrm{~nm}, n$-hexane/2-propanol, $70: 30,1.0 \mathrm{~mL} / \mathrm{min}, \mathrm{t}_{\mathrm{r}}($ minor $)=10.3 \mathrm{~min}, \mathrm{t}_{\mathrm{r}}$ (major) $=$ $13.1 \mathrm{~min}$.

(R)-4-nitro-1-phenyl-3-(pyridin-3-yl)butan-1-one (6am). Colourless oil; IR (ATR): $v=3035,2929,2857$, 1684, 1549, 1428, 1267, 1177, $1024 \mathrm{~cm}^{-1}$; ${ }^{1} \mathrm{H}$ NMR $(300$ $\left.\mathrm{MHz}, \mathrm{CDCl}_{3}\right): \delta_{H}=8.62(\mathrm{~d}, J=2.2 \mathrm{~Hz}, 1 \mathrm{H}), 8.54(\mathrm{dd}, J=$ $4.8,1.5 \mathrm{~Hz}, 1 \mathrm{H}), 7.96-7.88(\mathrm{~m}, 2 \mathrm{H}), 7.66(\mathrm{dt}, J=8.0,2.0$ $\mathrm{Hz}, 1 \mathrm{H}), 7.62-7.57$ (m, 2H), 7.50-7.44 (m, 2H), 7.31-7.28 $(\mathrm{m}, 1 \mathrm{H}), 4.88(\mathrm{dd}, J=12.8,6.4 \mathrm{~Hz}, 1 \mathrm{H}), 4.73(\mathrm{dd}, J=$ $12.8,8.1 \mathrm{~Hz}, 1 \mathrm{H}), 4.27(\mathrm{dd}, J=14.6,6.8 \mathrm{~Hz}, 1 \mathrm{H}), 3.50(\mathrm{~d}$, $J=6.9 \mathrm{~Hz}, 1 \mathrm{H}) \mathrm{ppm} ;{ }^{13} \mathrm{C} \mathrm{NMR}\left(75 \mathrm{MHz}, \mathrm{CDCl}_{3}\right): \delta_{C}=$ $196.1,149.2,149.0,136.1,135.3,134.9,133.8,128.8$, 128.0, 123.8, 78.9, 41.0, 36.9 ppm; MS (EI, $70 \mathrm{ev):} \mathrm{m} / \mathrm{z}$ $(\%)=207$ (69), 131 (11), 117 (34), 105 (100), 77 (51), 51 (17); HRMS $\left(\mathrm{CI}-\mathrm{CH}_{4}\right): \mathrm{m} / z$ calcd for $\mathrm{C}_{15} \mathrm{H}_{15} \mathrm{~N}_{2} \mathrm{O}_{3}$ $[\mathrm{M}+\mathrm{H}]^{+}$: 271,1077, found: 271.1070; HPLC: Chiralpak AS-H $, \lambda=210 \mathrm{~nm}, n$-hexane/2-propanol, $70: 30,1.0 \mathrm{~mL} / \mathrm{min}, \mathrm{t}_{\mathrm{r}}($ major $)=22.0 \mathrm{~min}, \mathrm{t}_{\mathrm{r}}($ minor $)=$ $38.2 \mathrm{~min}$.

(S)-3-(furan-2-yl)-4-nitro-1-phenylbutan-1-one (6an). ${ }^{16 c}$ Colourless oil; ${ }^{1} \mathrm{H}$ NMR $\left(400 \mathrm{MHz}, \mathrm{CDCl}_{3}\right): \delta_{H}$ $=8.01-7.91(\mathrm{~m}, 2 \mathrm{H}), 7.63-7.56(\mathrm{~m}, 1 \mathrm{H}), 7.52-7.44(\mathrm{~m}$, 2H), 7.34 (dd, $J=1.9,0.8 \mathrm{~Hz}, 1 \mathrm{H}), 6.29(\mathrm{dd}, J=3.3,1.9$ $\mathrm{Hz}, 1 \mathrm{H}), 6.19$ (d, $J=3.3 \mathrm{~Hz}, 1 \mathrm{H}), 4.81$ (dd, $J=12.6,6.1$ $\mathrm{Hz}, 1 \mathrm{H}), 4.75$ (dd, $J=12.6,7.3 \mathrm{~Hz}, 1 \mathrm{H}), 4.37-4.30$ (m, $1 \mathrm{H}), 3.53(\mathrm{dd}, J=17.9,6.1 \mathrm{~Hz}, 1 \mathrm{H}), 3.43(\mathrm{dd}, J=17.9$, $7.5 \mathrm{~Hz}, 1 \mathrm{H}) \mathrm{ppm} ;{ }^{13} \mathrm{C} \mathrm{NMR}\left(101 \mathrm{MHz}, \mathrm{CDCl}_{3}\right): \delta_{C}=$ $196.5,151.9,142.3,136.2,133.6,128.7,128.0,110.5$, 107.1, 77.2, 38.9, 33.1 ppm; HPLC: Chiralpak AS-H , $\lambda=$ $210 \mathrm{~nm}, \quad n$-hexane/2-propanol, 70:30, $1.0 \mathrm{~mL} / \mathrm{min}, \mathrm{t}_{\mathrm{r}}$ $($ minor $)=8.7 \mathrm{~min}, \mathrm{t}_{\mathrm{r}}($ major $)=9.7 \mathrm{~min}$.

(R)-5-nitro-4-phenylpentan-2-one (6oa). ${ }^{25}$ White solid, mp 113-114 ${ }^{\circ} \mathrm{C} ;{ }^{1} \mathrm{H}$ NMR $\left(300 \mathrm{MHz}, \mathrm{CDCl}_{3}\right): \delta_{H}=7.34$ $7.19(5 \mathrm{H}, \mathrm{m}), 4.68(\mathrm{dd}, J=12.3,6.9 \mathrm{~Hz}, 1 \mathrm{H}), 4.58(\mathrm{dd}, J$ $=12.3,7.9 \mathrm{~Hz}, 1 \mathrm{H}), 4.06-3.96(\mathrm{~m}, 1 \mathrm{H}), 2.90(\mathrm{~d}, J=7.0$ $\mathrm{Hz}, 2 \mathrm{H}), 2.09$ (s, 3H) ppm; ${ }^{13} \mathrm{C}$ NMR $\left(75 \mathrm{MHz}, \mathrm{CDCl}_{3}\right)$ : $\delta_{C}=205.4,138.8,129.0,127.8,127.3,79.4,46.0,39.0$, 30.3 ppm; HPLC: Chiralpak AS-H, $\lambda=210 \mathrm{~nm}, n-$ hexane/2-propanol, 75:25, $1.0 \mathrm{~mL} / \mathrm{min}, \mathrm{t}_{\mathrm{r}}$ (minor) $=9.5$ $\min , \mathrm{t}_{\mathrm{r}}($ major $)=11.4 \mathrm{~min}$.

(R)-5-nitro-4-(p-tolyl)pentan-2-one (6ob).$^{25}$ White solid, mp 66-68 ${ }^{\circ} \mathrm{C}$; ${ }^{1} \mathrm{H}$ NMR $\left(300 \mathrm{MHz}, \mathrm{CDCl}_{3}\right): \delta_{H}=7.16-$ $7.06(\mathrm{~m}, 4 \mathrm{H}), 4.67(\mathrm{dd}, J=12.2,6.9 \mathrm{~Hz}, 1 \mathrm{H}), 4.57(\mathrm{dd}, J$ $=12.2,7.7 \mathrm{~Hz}, 1 \mathrm{H}), 4.01-3.92(\mathrm{~m}, 1 \mathrm{H}), 2.89(\mathrm{~d}, J=7.1$ $\mathrm{Hz}, 2 \mathrm{H}), 2.31(\mathrm{~s}, 3 \mathrm{H}), 2.11(\mathrm{~s}, 3 \mathrm{H}) \mathrm{ppm} ;{ }^{13} \mathrm{C}$ NMR $(75$ $\left.\mathrm{MHz}, \mathrm{CDCl}_{3}\right): \delta_{C}=205.5,137.6,135.7,129.7,127.2$, 79.6, 46.2 38.7, 30.4, 21.0 ppm; HPLC: Chiralpak AS-H, $\lambda=210 \mathrm{~nm}, n$-hexane/2-propanol, $80: 20,1.0 \mathrm{~mL} / \mathrm{min}, \mathrm{t}_{\mathrm{r}}$ $($ minor $)=9.4 \min , \mathrm{t}_{\mathrm{r}}($ major $)=12.4 \mathrm{~min}$. 
(R)-4-(4-methoxyphenyl)-5-nitropentan-2-one $\quad\left(\right.$ 6oc). ${ }^{25}$ White solid, mp 93-94 ${ }^{\circ} \mathrm{C} ;{ }^{1} \mathrm{H}$ NMR (300 MHz, $\mathrm{CDCl}_{3}$ ): $\delta_{H}=7.13(\mathrm{~d}, J=8.7 \mathrm{~Hz}, 2 \mathrm{H}), 6.85(\mathrm{~d}, J=8.7 \mathrm{~Hz}, 2 \mathrm{H}) 4.66$ (dd, $J=12.2,6.9 \mathrm{~Hz}, 1 \mathrm{H}), 4.55(\mathrm{dd}, \mathrm{J}=12.2,7.8 \mathrm{~Hz}, 1 \mathrm{H})$, 4.00-3.91 (m, 1H), 2.88 (d, $J=7.1 \mathrm{~Hz}, 2 \mathrm{H}), 3.78$ (s, 3H), $2.11(\mathrm{~s}, 3 \mathrm{H}) \mathrm{ppm} ;{ }^{13} \mathrm{C} \mathrm{NMR}\left(75 \mathrm{MHz}, \mathrm{CDCl}_{3}\right): \delta_{C}=$ 205.6, 159.1, 130.6, 128.4, 114.4, 79.7, 55.3, 46.3, 38.4, 30.4 ppm; HPLC: Chiralpak AS-H, $\lambda=210 \mathrm{~nm}, n-$ hexane/2-propanol, 70:30, $1.0 \mathrm{~mL} / \mathrm{min}, \mathrm{t}_{\mathrm{r}}($ minor $)=15.9$ $\min , \mathrm{t}_{\mathrm{r}}($ major $)=29.1 \mathrm{~min}$.

(R)-4-(4-fluorophenyl)-5-nitropentan-2-one $\quad$ (6of). ${ }^{26}$ White solid, mp 81-82 ${ }^{\circ} \mathrm{C} ;{ }^{1} \mathrm{H}$ NMR (300 MHz, $\mathrm{CDCl}_{3}$ ): $\delta_{H}=7.22-7.18(\mathrm{~m}, 2 \mathrm{H}), 7.04-6.99(\mathrm{~m}, 2 \mathrm{H}), 4.68(\mathrm{dd}, J=$ $12.4,6.6 \mathrm{~Hz}, 1 \mathrm{H}), 4.57(\mathrm{dd}, J=12.4,7.9 \mathrm{~Hz}, 1 \mathrm{H}), 4.05-$ $3.95(\mathrm{~m}, 1 \mathrm{H}), 2.90(\mathrm{~d}, J=7.0 \mathrm{~Hz}, 2 \mathrm{H}), 2.12$ (s, 3H) ppm; ${ }^{13} \mathrm{C}$ NMR $\left(75 \mathrm{MHz}, \mathrm{CDCl}_{3}\right): \delta_{C}=205.1,162.2(\mathrm{~d}, J=$ $246.7 \mathrm{~Hz}), 134.6(\mathrm{~d}, J=3.4 \mathrm{~Hz}), 129.0(\mathrm{~d}, J=8.2 \mathrm{~Hz})$, $115.97(\mathrm{~d}, J=21.6 \mathrm{~Hz}), 79.4,46.1,38.3,30.3 \mathrm{ppm}$; HPLC: Chiralpak AS-H $, \lambda=210 \mathrm{~nm}, \quad n$-hexane/2propanol, 70:30, $1.0 \mathrm{~mL} / \min , \mathrm{t}_{\mathrm{r}}($ minor $)=9.2 \mathrm{~min}, \mathrm{t}_{\mathrm{r}}$ $($ major $)=11.8 \mathrm{~min}$.

(R)-4-(4-chlorophenyl)-5-nitropentan-2-one $\quad(6 \mathrm{oh}) .^{25}$ White solid, mp 90-92 ${ }^{\circ} \mathrm{C} ;{ }^{1} \mathrm{H}$ NMR (300 MHz, $\mathrm{CDCl}_{3}$ ): $\delta_{H}=7.31(\mathrm{~d}, J=8.5 \mathrm{~Hz}, 2 \mathrm{H}), 7.16(\mathrm{~d}, J=8.5 \mathrm{~Hz}, 2 \mathrm{H})$, $4.68(\mathrm{dd}, J=12.4,6.6 \mathrm{~Hz}, 1 \mathrm{H}), 4.57(\mathrm{dd}, J=12.4,7.9 \mathrm{~Hz}$, $1 \mathrm{H}), 4.04-3.96(\mathrm{~m}, 1 \mathrm{H}), 2.90(\mathrm{~d}, J=7.0 \mathrm{~Hz}, 2 \mathrm{H}), 2.13(\mathrm{~s}$, $3 \mathrm{H}) \mathrm{ppm} ;{ }^{13} \mathrm{C}$ NMR $\left(75 \mathrm{MHz}, \mathrm{CDCl}_{3}\right): \delta_{C}=205.0,137.3$, 133.8, 129.2, 128.8, 79.2, 45.9, 38.4, 30.4 ppm; HPLC: Chiralpak AS-H $, \lambda=210 \mathrm{~nm}, n$-hexane/2-propanol, $70: 30,1.0 \mathrm{~mL} / \mathrm{min}, \mathrm{t}_{\mathrm{r}}($ minor $)=11.2 \mathrm{~min}, \mathrm{t}_{\mathrm{r}}$ (major) $=$ $15.5 \mathrm{~min}$.

(R)-5-nitro-4-(4-(trifluoromethyl)phenyl)pentan-2-one (6oj). ${ }^{27}$ Colourless oil; ${ }^{1} \mathrm{H}$ NMR $\left(400 \mathrm{MHz}, \mathrm{CDCl}_{3}\right): \delta_{H}=$ $7.60(\mathrm{~d}, J=8.1 \mathrm{~Hz}, 2 \mathrm{H}), 7.36(\mathrm{~d}, J=8.1 \mathrm{~Hz}, 2 \mathrm{H}), 4.73$ (dd, $J=12.6,6.5 \mathrm{~Hz}, 1 \mathrm{H}), 4.62(\mathrm{dd}, J=12.6,8.0 \mathrm{~Hz}, 1 \mathrm{H})$, 4.14-4.03 (m, 1H), $2.94(\mathrm{dd}, J=6.9,0.9 \mathrm{~Hz}, 2 \mathrm{H}), 2.14$ (s, $3 \mathrm{H}) \mathrm{ppm} ;{ }^{13} \mathrm{C}$ NMR $\left(101 \mathrm{MHz}, \mathrm{CDCl}_{3}\right): \delta_{C}=204.7$, $142.9,130.2(\mathrm{q}, J=32.8 \mathrm{~Hz}), 127.9,126.0,123.8(\mathrm{~d}, J=$ $272.2 \mathrm{~Hz}), \quad 78.8, \quad 45.8, \quad 38.6, \quad 30.3 \mathrm{ppm}$; HPLC: Chiralpak AS-H $, \lambda=210 \mathrm{~nm}, n$-hexane/2-propanol, $70: 30,1.0 \mathrm{~mL} / \mathrm{min}, \mathrm{t}_{\mathrm{r}}$ (minor) $=6.5 \mathrm{~min}, \mathrm{t}_{\mathrm{r}}$ (major) $=7.8$ $\min$.

(R)-4-(naphthalen-2-yl)-5-nitropentan-2-one $\quad(60 l) .^{27}$ White solid, mp 101-103 ${ }^{\circ} \mathrm{C}$; ${ }^{1} \mathrm{H}$ NMR $(300 \mathrm{MHz}$, $\left.\mathrm{CDCl}_{3}\right): \delta_{H}=7.86-7.78(\mathrm{~m}, 3 \mathrm{H}), 7.68(\mathrm{~d}, J=1.5 \mathrm{~Hz}, 1 \mathrm{H})$, 7.53-7.45 (m, 2H), 7.34 (dd, $J=8.5,1.8 \mathrm{~Hz}, 1 \mathrm{H}), 4.78$ $(\mathrm{dd}, J=12.4,6.9 \mathrm{~Hz}, 1 \mathrm{H}), 4.70(\mathrm{dd}, J=12.4,7.7 \mathrm{~Hz}, 1 \mathrm{H})$, 4.25-4.14 (m, 1H), 3.00 (d, $J=7.0 \mathrm{~Hz}, 2 \mathrm{H}), 2.13$ (s, 3H); ${ }^{13} \mathrm{C}$ NMR: $\left(75 \mathrm{MHz}, \mathrm{CDCl}_{3}\right): \delta_{C}=205.3,136.1,133.3$, $132.8,128.9,127.8,127.6,126.5,126.2,125.0,79.3$, 46.1, 39.1, 30.4 ppm; HPLC: Chiralpak AS-H , $\lambda=210$ $\mathrm{nm}, n$-hexane/2-propanol, 70:30, $1.0 \mathrm{~mL} / \mathrm{min}, \mathrm{t}_{\mathrm{r}}($ minor $)=$ $10.4 \min , \mathrm{t}_{\mathrm{r}}$ (major) $=14.4 \mathrm{~min}$.
(S)-4-(furan-2-yl)-5-nitropentan-2-one

(6on)..$^{25}$ Colourless oil; ${ }^{1} \mathrm{H}$ NMR $\left(300 \mathrm{MHz}, \mathrm{CDCl}_{3}\right): \delta_{H}=7.35-$ $7.33(\mathrm{~m}, 1 \mathrm{H}), 6.30(\mathrm{dd}, J=3.2,1.9 \mathrm{~Hz}, 1 \mathrm{H}), 6.15(\mathrm{~d}, J=$ $3.3 \mathrm{~Hz}, 1 \mathrm{H}), 4.68$ (dd, $J=6.6,1.6 \mathrm{~Hz}, 2 \mathrm{H}), 4.15-406$ (m, $1 \mathrm{H}), 2.94(\mathrm{dd}, J=8.3,7.0 \mathrm{~Hz}, 2 \mathrm{H}), 2.18(\mathrm{~s}, 3 \mathrm{H}) \mathrm{ppm} ;{ }^{13} \mathrm{C}$ NMR $\left(75 \mathrm{MHz}, \mathrm{CDCl}_{3}\right): \delta_{C}=205.0,151.6,142.3,110.5$, 107.1, 77.2, 43.5, 32.9, 30.2 ppm; HPLC: Chiralpak AD$\mathrm{H}, \lambda=210 \mathrm{~nm}, n$-hexane/2-propanol, $90: 10,1.0 \mathrm{~mL} / \mathrm{min}$, $\mathrm{t}_{\mathrm{r}}($ major $)=26.4 \mathrm{~min}, \mathrm{t}_{\mathrm{r}}($ minor $)=29.3 \mathrm{~min}$.

4.3. Calculations. The structures were optimized by using density functional theory (DFT) with the B3LYP ${ }^{28}$ and the 6-31G* basis set as implemented in Gaussian 09. ${ }^{29}$ The structures were re-optimized at M06-2X/6-311+G** level of theory ${ }^{30}$ on the previously optimized structures, ${ }^{31}$ including polarization functions for better description of hydrogen bond activations and to better account for the dispersion forces of such large systems. Besides, solvation factors were introduced with the IEF-PCM method, ${ }^{32}$ using water as indicated in the text and figures.

We also performed single-point calculations at B3LYP-D3/6-311+G** level of theory, including Grimme's dispersion with the original D3 damping function, and the relative values were similar to those of the M06-2X energies. ${ }^{33}$ The stationary points were characterized by frequency calculations in order to verify that they have the right number of imaginary frequencies. The intrinsic reaction coordinates (IRC) ${ }^{34}$ were followed to verify the energy profiles connecting each TS to the correct associated local minima. 3D structures were drawn using the CyL view software. ${ }^{35}$

\section{Acknowledgments}

We thank the financial support from the Spanish Ministerio de Economía y Competitividad (project CTQ2011-24151), FEDER, the COST Action CM0905 "Organocatalysis", the FP7 Marie Curie Action of the European Commission via the ITN ECHONET Network (FP7-MCITN-2012-316379), and the universities of Alicante and the Basque Country. We also thank SGI/IZO-SGIker (UPV/EHU) and University of Szeged, Department of Chemical Informatics for allocation of computational resources. J. F.-F. acknowledges the Vicerrectorado de Investigación, Desarrollo e Innovación of the University of Alicante for a fellowship. A. S. thanks the University of Edimburgh for an ERASMUS fellowship.

\section{References}

1. (a) Zou, W.; Vembaiyan, K.; Bhasin, M.; Williams, D. T. Carbohydr. Res. 2009, 344, 2144-2150; (b) Pansare, S. V.; Lingampally, R.; Kirby, R. L. Org. Lett. 2010, 12, 556559.

2. (a) Ma, H.; Liu, K.; Zhang, F.-G.; Zhu, C.-L.; Nie, J.; Ma, J.-A. J. Org. Chem. 2010, 75, 1402-1409; (b) Nakamura, A.; Lectard, S.; Hashizume, D.; Hamashima, Y.; Sodeoka, M. J. Am. Chem. Soc. 2010, 132, 4036-4037. 
3. Szanto, G.; Hegedus, L.; Mattyasovszky, L.; Simon, A.; Simon, A.; Bitter, I.; Toth, G.; Toke, L.; Kadas, I. Tetrahedron 2009, 65, 8412-8417.

4. Andrey, O.; Vidonne, A.; Alexakis, A. Tetrahedron Lett. 2003, 44, 7901-7904.

5. Yu, Z.; Liu, X.; Zhou, L.; Lin, L.; Feng, X. Angew. Chem. Int. Ed. 2009, 48, 5195-5198.

6. Hong, B.-C.; Kotame, P.; Tsai, C.-W.; Liao, J.-H. Org. Lett. 2010, 12, 776-779.

7. (a) Elsner, P.; Jiang, H.; Nielsen, J. B.; Pasi, F.; Jorgensen, K. A. Chem. Commun. 2008, 5827-5829; (b) Karthikeyan, T.; Sankararaman, S. Tetrahedron: Asymmetry 2008, 19 , 2741-2745; (c) Ruiz, N.; Reyes, E.; Vicario, J. L.; Badia, D.; Carrillo, L.; Uria, U. Chem. Eur. J. 2008, 14, 93579367; (d) Krayer, M.; Ptaszek, M.; Kim, H.-J.; Meneely, K. R.; Fan, D.; Secor, K.; Lindsey, J. S. J. Org. Chem. 2010, $75,1016-1039$.

8. (a) Sulzer-Mosse, S.; Alexakis, A. Chem. Commun. 2007 , 3123-3135; (b) Almasi, D.; Alonso, D. A.; Nájera, C. Tetrahedron: Asymmetry 2007, 18, 299-365; (c) Tsogoeva, S. B. Eur. J. Org. Chem. 2007, 1701-1716; (d) Peng, F.; Shao, Z. J. Mol. Catal. A: Chem. 2008, 285, 1-13; (e) Roca-Lopez, D.; Sadaba, D.; Delso, I.; Herrera, R. P.; Tejero, T.; Merino, P. Tetrahedron: Asymmetry 2010, 21, 2561-2601; (f) Somanathan, R.; Chavez, D.; Servin, F. A.; Romero, J. A.; Navarrete, A.; Parra-Hake, M.; Aguirre, G.; Anaya, d. P. C.; Gonzalez, J. Curr. Org. Chem. 2012, 16, 2440-2461; (g) Serdyuk, O. V.; Heckel, C. M.; Tsogoeva, S. B. Org. Biomol. Chem. 2013, 11, 7051-7071; (h) Aitken, L. S.; Arezki, N. R.; Dell'Isola, A.; Cobb, A. J. A. Synthesis 2013, 45, 2627-2648.

9. Kerr, D. I. B.; Ong, J. Med. Res. Rev. 1992, 12, 593-636.

10. (a) Olpe, H. R.; Demieville, H.; Baltzer, V.; Bencze, W. L.; Koella, W. P.; Wolf, P.; Haas, H. L. Eur. J. Pharmacol. 1978, 52, 133-136; (b) Berthelot, P.; Vaccher, C.; Flouquet, N.; Debaert, M.; Luyckx, M.; Brunet, C. J. Med. Chem. 1991, 34, 2557-60; (c) Kerr, D. I. B.; Ong, J.; Doolette, D. J.; Abbenante, J.; Prager, R. H. Eur. J. Pharmacol. 1993, 236, 239-45.

11. Lapin, I. CNS Drug Rev. 2001, 7, 471-481

12. Enders, D.; Seki, A. Synlett 2002, 26-28.

13. (a) Betancort, J. M.; Sakthivel, K.; Thayumanavan, R.; Tanaka, F.; Barbas, C. F., III Synthesis 2004, 1509-1521; (b) Xu, D.-Z; Shi, S.; Wang, Y. Eur. J. Org. Chem. 2009, 4848-4853; (c) Barbayianni, E.; Bouzi, P.; ConstantinouKokotou, V.; Ragoussis, V.; Kokotos, G. Heterocycles 2009, 78, 1243-1252; (d) Chandrasekhar, S.; Kumar, T. P.; Haribabu, K.; Reddy, C. R.; Kumar, C. R. Tetrahedron: Asymmetry 2011, 22, 697-702.

14. Liu, J.; Yang, Z.; Liu, X.; Wang, Z.; Liu, Y.; Bai, S.; Lin, L.; Feng, X. Org. Biomol. Chem. 2009, 7, 4120-4127.

15. (a) Xue, F.; Zhang, S.; Duan, W.; Wang, W. Adv. Synth Catal. 2008, 350, 2194-2198; (b) Rasappan, R.; Reiser, O. Eur. J. Org. Chem. 2009, 1305-1308.

16. (a) Huang, H.; Jacobsen, E. N. J. Am. Chem. Soc. 2006, 128, 7170-7171; (b) Liu, K.; Cui, H.-F.; Nie, J.; Dong, K.Y.; Li, X.-J.; Ma, J.-A. Org. Lett. 2007, 9, 923-925; (c) Jiang, X.; Zhang, Y.; Chan, A. S. C.; Wang, R. Org. Lett. 2009, 11, 153-156; (d) Kokotos, C. G.; Kokotos, G. Adv. Synth. Catal. 2009, 351, 1355-1362; (e) Li, B.-L.; Wang, Y.-F.; Luo, S.-P.; Zhong, A.-G.; Li, Z.-B.; Du, X.-H.; Xu, D.-Q. Eur. J. Org. Chem. 2010, 656-662; (f) Wang, L.; $\mathrm{Xu}, \mathrm{X}$.; Huang, J.; Peng, L.; Huang, Q.; Wang, L. Lett. Org. Chem. 2010, 7, 367-372; (g) Sun, Z.-W.; Peng, F.-Z.; Li, Z.-Q.; Zou, L.-W.; Zhang, S.-X.; Li, X.; Shao, Z.-H. J.
Org. Chem. 2012, 77, 4103-4110; (h) Tsakos, M.; Kokotos, C. G.; Kokotos, G. Adv. Synth. Catal. 2012, 354 , 740-746; (i) Orlandi, S.; Pozzi, G.; Ghisetti, M.; Benaglia, M. New J. Chem. 2013, 37, 4140-4147; (j) Yu, L.; Li, P. Tetrahedron Lett. 2014, 55, 3697-3700.

17. (a) Flores-Ferrándiz, J.; Chinchilla, R. Tetrahedron: Asymmetry 2014, 25, 1091-1094; (b) Flores-Ferrándiz, J.; Fiser, B.; Gómez-Bengoa, E.; Chinchilla, R. Eur. J. Org. Chem. 2015, 1218-1225.

18. Avila, A.; Chinchilla, R.; Gómez-Bengoa, E.; Nájera, C. Eur. J. Org. Chem. 2013, 5085-5092.

19. Chi, Y.; Guo, L.; Kopf, N. A.; Gellman, S. H. J. Am Chem. Soc. 2008, 130, 5608-5609.

20. (a) Seebach, D.; Golinski, J. Helv. Chim. Acta 1981, 64, 1413-1423; (b) Seebach, D.; Beck, A. K.; Golinski, J.; Hay, J. N.; Laube, T. Helv. Chim. Acta 1985, 68, 162-172.

21. Rodríguez, J. M.; Pujol, M. D. Tetrahedron Lett. 2011, 52, 2629-2632.

22. Kuster, G. J. T.; Steeghs, R. H. J.; Scheeren, H. W. Eur. J. Org. Chem. 2001, 553-560.

23. Evans, D. A.; Mito, S.; Seidel, D. J. Am. Chem. Soc. 2007, 129, 11583-11592.

24. Blay, G.; Incerti, C.; Muñoz, M. C.; Pedro, J. R. Eur. J. Org. Chem. 2013, 1696-1705.

25. Lu, A.; Liu, T.; Wu, R.; Wang, Y.; Zhou, Z.; Wu, G.; Fang, J.; Tang, C. Eur. J. Org. Chem. 2010, 5777-5781.

26. Peng, L.; Xu, X.-Y.; Wang, L.-L.; Huang, J.; Bai, J.-F.; Huang, Q.-C.; Wang, L.-X. Eur. J. Org. Chem. 2010, 1849-1853.

27. Akagawa, K.; Suzuki, R.; Kudo, K. Asian J. Org. Chem. 2014, 3, 514-522

28. (a) Lee, C.; Yang, W.; Parr, R. G. Phys. Rev. B 1988, 37, 785-789; (b) Becke, A. D. J. Chem. Phys. 1993, 98, 56485652; (c) Kohn, W.; Becke, A. D.; Parr, R. G. J. Phys. Chem. 1996, 100, 12974-12980.

29. Frisch, M. J.; Trucks, G. W.; Schlegel, H. B.; Scuseria, G. E.; Robb, M. A.; Cheeseman, J. R.; Scalmani, G.; Barone, V.; Menucci, B., Petersson, G. A.; Nakatsuji, H.; Caricato, M.; Li, X.; Hratchian, H. P.; Izmaylov, A. F.; Bloino, J.; Zheng, G.; Sonnenberg, J. L.; Hada, M.; Ehara, M.; Toyota, K.; Fukuda, R.; Hasegawa, J.; Ishida, M.; Nakajima, T.; Honda, Y.; Kitao, O.; Nakai, H.; Vreven, T.; Montgomery, J. A., Jr.; Peralta, J. E.; Ogliaro, F.; Bearpark, M.; Heyd, J. J.; Brothers, E.; Kudin,. K. N.; Staroverov, V. N; Kobayashi, R.; Normand, J.; Raghavachari, K.; Rendell, A.; Burant, J. C.; Iyengar, S. S.; Tomasi, J.; Cossi, M.; Rega, N.; Millam, J. M.; Klene, M.; Knox, J. E.; Cross, J. B.; Bakken, V.; Adamo, C.; Jaramillo, J.; Gomperts, R.; Stratmann, R. E.; Yazyev, O.; Austin, A. J.; Cammi, R.; Pomelli, C.; Ochterski, J. W.; Martin, R. L.; Morokuma, K.; Zakrewski, V. G.; Voth, G. A.; Salvador, P.; Dannenberg, J. J.; Dapprich, S.; Daniels, A. D.; Farkas, O.; Foresman, J. B.; Ortiz, J. V.; Cioslowski, J.; Fox, D. J. Gaussian 09, Revision D.01, Gaussian, Inc., Wallingford CT, 2009.

30. Zhao, Y.; Truhlar, D. G.; Theor. Chem. Acc. 2008, 120, 215-241.

31. The use of the M06-2X/6-311+G** (or closely related method) level of theory has been justified in previous $\mathrm{H}$ bond organocatalyzed reactions. See for example: (a) Kótai, B.; Kardos, G.; Hamza, A.; Farkas, V.; Pápai, I.; Soós, T. Chem. Eur. J. 2014, 20, 5631-5639; (b) Simón, L.; Goodman, J. M. Org. Biomol. Chem. 2011, 9, 689-700. 
32. (a) Cancès, E.; Mennucci, B.; Tomasi, J. J. Chem. Phys. 1997, 107, 3032-3047. (b) Tomasi, J.; Mennucci, B.; Cancès, E. J. Mol. Struct. (Theochem) 1999, 464, 211-226.

33. Grimme, S.; Antony, J.; Ehrlich, S.; Krieg, H. J. Chem. Phys. 2010, 132, 154104/1-154104/19.

34. Gonzalez, C.; Schlegel, H. B. J. Phys. Chem. 1990, 94, 5523-5527.

35. Legault, C. Y.; CYLview, v. 1.0b, Université de Sherbrooke, 2009 (http://www.cylview.org). 